\title{
Temperature Data Evaluation
}

\author{
prepared by \\ David Gillespie \\ submitted to \\ Nevada Site Office \\ National Nuclear Security Administration \\ U.S. Department of Energy \\ Las Vegas, Nevada
}

MARCH 2003

\section{Publication No. 45194}


Reference herein to any specific commercial product, process, or service by trade name, trademark, manufacturer, or otherwise, does not necessarily constitute or imply its endorsement, recommendation, or favoring by the United States Government or any agency thereof or its contractors or subcontractors. The views and opinions of authors expressed herein do not necessarily state or reflect those of the United States Government or any agency thereof.

This report has been reproduced directly from the best available copy.

Available for sale to the public, in paper, from:

U.S. Department of Commerce

National Technical Information Service

5285 Port Royal Rd.

Springfield, VA 22161

phone: 800.553 .6847

fax: 703.605.6000

email: order@ntis.fedworld.gov

online ordering: http://www.ntis.gov/ordering.htm

Available electronically at http://www.doe.gov/bridge

Available for a processing fee to the U.S. Department of Energy and its contractors, in paper, from:

U.S. Department of Energy

Office of Scientific and Technical Information

P.O. Box 62

Oak Ridge, TN 37831-0062

phone: 423.576 .8401

fax: 423.576 .5728

email: reports@adonis.osti.gov 


\title{
Temperature Data Evaluation
}

\author{
Prepared by \\ David Gillespie \\ Division of Hydrologic Sciences \\ Desert Research Institute \\ University and Community College System of Nevada \\ Publication No. 45194 \\ Submitted to \\ Nevada Site Office \\ National Nuclear Security Administration \\ U.S. Department of Energy \\ Las Vegas, Nevada
}

March 2003

The work upon which this report is based was supported by the U.S. Department of Energy under Contract \#DE-AC08-00NV13609. Approved for public release; further dissemination unlimited. 



\section{ABSTRACT}

Groundwater temperature is sensitive to the competing processes of heat flow from below and the advective transport of heat by groundwater flow. Because groundwater temperature is sensitive to conductive and advective processes, groundwater temperature may be utilized as a tracer to further constrain the uncertainty of predictions of advective radionuclide transport models constructed for the Nevada Test Site (NTS). Since heat transport, geochemical, and hydrologic models for a given area must all be consistent, uncertainty can be reduced by devaluing the weight of those models that do not match estimated heat flow.

The objective of this study was to identify the quantity and quality of available heat flow data at the NTS. Although thousands of temperature logs have been conducted at the NTS, most are recorded on paper and not easily examined. In this investigation, only those temperature logs in digital format were considered.

In this investigation, 145 temperature logs from 63 boreholes on the NTS were examined. Of these, 13 boreholes were found to have temperature profiles suitable for the determination of heat flow values from one or more intervals within the boreholes. Heat flow values for intervals contained within the 13 boreholes ranged from a low of $7.5 \mathrm{~mW} \mathrm{~m}$ to a high of $110.2 \mathrm{~mW} \mathrm{~m}^{-2}$. Vertical variations in heat flow values, within individual boreholes, were readily explained by the advection of heat by groundwater flow. Horizontal consistencies and variations in heat flow values between various boreholes were dependent upon the geologic setting of the borehole, and the effect of vertical fluid movement.

Temperature profiles are extremely easy and inexpensive to obtain. Considerable hydrologic information can be determined from the examination of a single temperature profile from a well in which drilling-induced temperature disturbances have dissipated. Interpretation of a temperature profile in a lithology without major variations in thermal conductivity may be fairly straightforward; interpretation of a temperature profile crossing several hydrostratigraphic units requires accurate knowledge of the thermal properties of the corresponding hydrostratigraphic units. If sufficient spatially distributed heat flow values are obtained, a heat transport model coupled to a hydrologic model may be used to reduce the uncertainty of a non-isothermal hydrologic model of the NTS.

\section{ACKNOWLEDGEMENTS}

The author wishes to acknowledge George Juniel for his assistance in providing digital temperature profiles from Bechtel geophysical log archives at the NTS. The author would also like to acknowledge Jackie Kenneally, Brad Lyles, Todd Mihevc, and Dee Donithan for providing temperature profiles from various boreholes at the NTS obtained during their previous investigations; and to Chuck Russell, Ron Hershey, Marjory Jones, Ken Rehfeldt, Andrew Wolfsberg, Ed Kwicklis, and Jenny Boryta for their review and comments on the manuscript. The author would also like to thank the U.S. Department of Energy (DOE) and the DOE Underground Test Area project manager, Bob Bangerter, for providing funding to accomplish the work described herein. 


\section{CONTENTS}

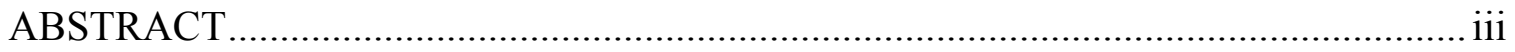

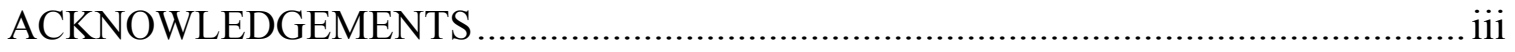

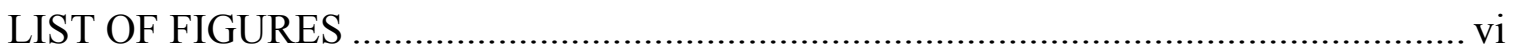

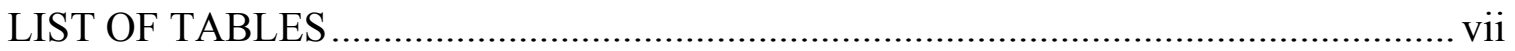

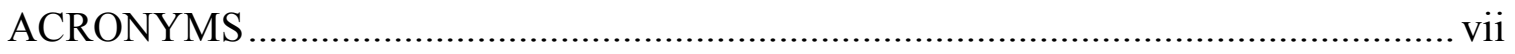

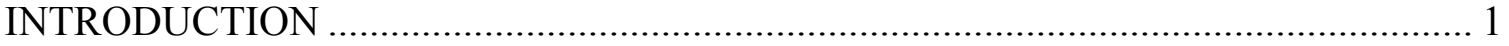

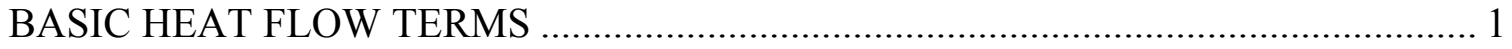

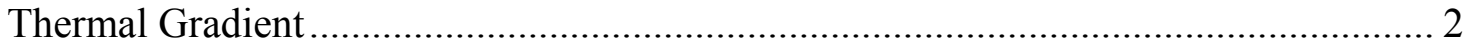

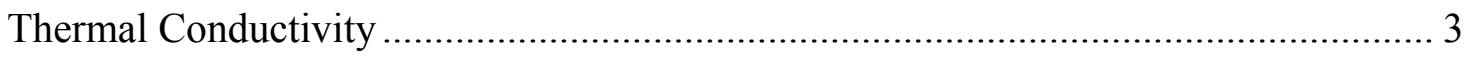

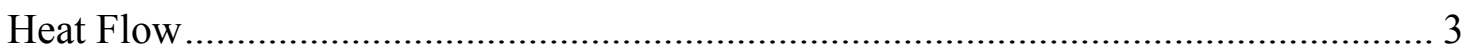

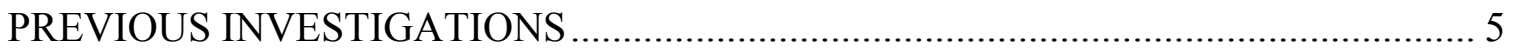

EVALUATION OF EXISTING NTS TEMPERATURE LOGS ...................................... 6

HEAT FLOW VALUES FOR NTS WELLS WITH SUITABLE TEMPERATURE

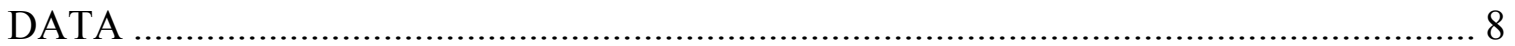

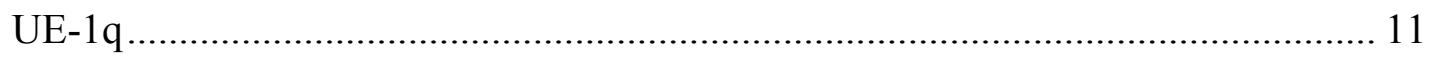

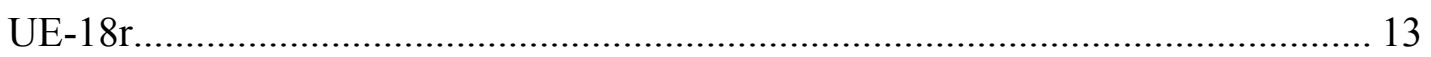

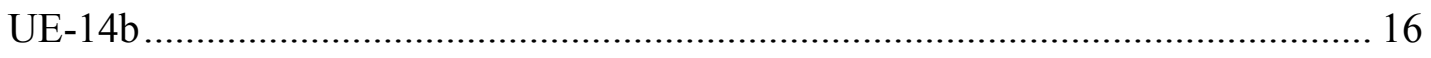

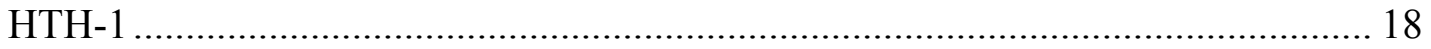

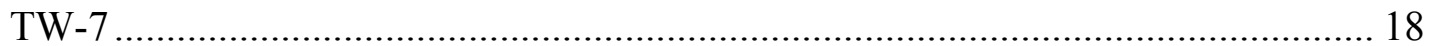

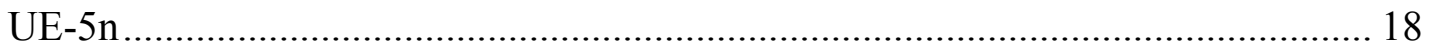

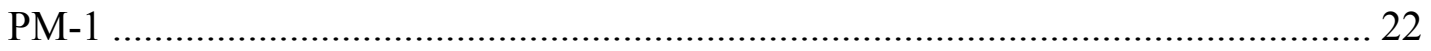

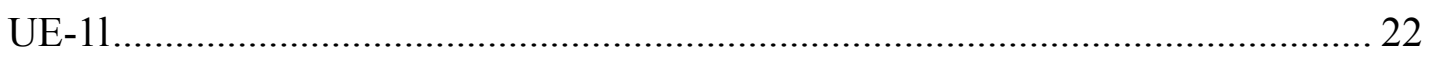

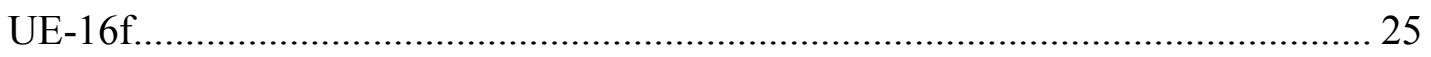

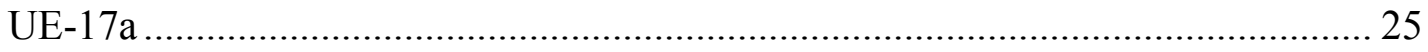

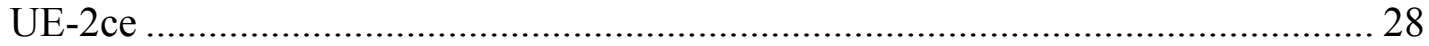

Amargosa Test Hole \#1 and Amargosa Test Hole \#2............................................ 28

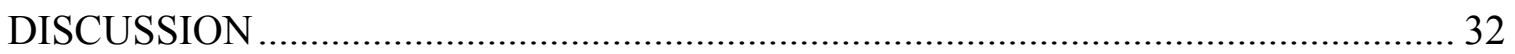

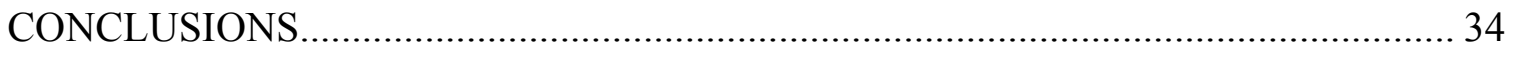

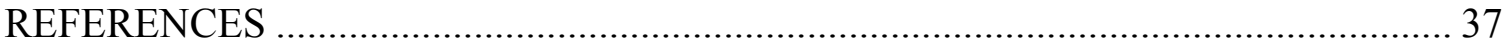




\section{LIST OF FIGURES}

1. Relationship between temperature, thermal gradient, thermal conductivity, and heat flow in a purely conductive thermal regime.............................................. 4

2. Location of boreholes at the NTS with temperature logs examined in this investigation

3. Laboratory measured thermal conductivity values $\left(\mathrm{W} \mathrm{m}^{-1 \circ} \mathrm{C}^{-1}\right)$ for Tertiary volcanic lithologies, Sass et al. (1987).

4. Location of boreholes on, or near, NTS with temperature profiles suitable for calculation of heat flow values.

5. Temperature profile, lithology and well construction for borehole UE-1q. ............ 12

6. Temperature profile, lithology, and well construction for borehole UE-18r........... 14

7. Comparison of temperature logs from UE-18r obtained by Atlas Wireline Services on March 13, 1993 and DRI on August 31, 1994.

8. Cross plot of temperature values between 425 and $496 \mathrm{~m}$ below ground surface obtained in UE-18r approximately 1 year and 5 months apart. ............................. 16

9. Temperature profile, lithology, and well construction for borehole UE-14b......... 17

10. Temperature profile, lithology, and well construction for borehole HTH-1 .......... 19

11. Temperature profile, lithology, and well construction for borehole TW-7 ............ 20

12. Temperature profile, lithology, and well construction for borehole UE-5n........... 21

13. Temperature profile, lithology, and well construction for borehole PM-1............ 23

14. Temperature profile, lithology, and well construction for borehole UE-11............ 24

15. Temperature profile, lithology, and well construction for borehole UE-16f........... 26

16. Temperature profile, lithology, and well construction for borehole UE-17a. ......... 27

17. Temperature profile, lithology, and well construction for borehole UE-2ce........... 29

18. Temperature profile, lithology, and well construction for borehole Amargosa

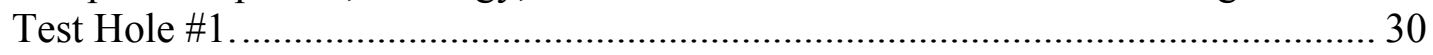

19. Temperature profile, lithology, and well construction for borehole Amargosa Test Hole \#2.

20. Heat flow values for 13 wells investigated in this study. 33 


\section{LIST OF TABLES}

1. Heat flow values from Sass and Lachenbruch (1982) ............................................. 6

2. Thermal conductivity of major volcanic rock types at the NTS from Sass et al. (1987)............................................................................................. 9

3. Typical rock thermal conductivity values from Wright and Louden (1989)............ 10

4. Typical rock thermal conductivity values from Johnston et al. (1981).................... 10

\section{ACRONYMS}

ATH1 Amargosa Test Hole \#1

ATH2 Amargosa Test Hole \#2

DOE U.S. Department of Energy

DRI Desert Research Institute

LLNL Lawrence Livermore National Laboratory

NTS Nevada Test Site

UGTA Underground Test Area 



\section{INTRODUCTION}

Groundwater temperature is sensitive to the competing processes of heat flow from below and the advective transport of heat by groundwater flow. Existing geophysical temperature data were evaluated in terms of well construction, and conditions under which the data were collected, to ascertain if a particular temperature $\log$ was representative of formation temperatures. Appropriate data were then compiled and registered in three dimensions and a simple visualization of the data set was constructed.

Because groundwater temperature is sensitive to conductive and advective processes, groundwater temperature may be utilized as a tracer to further constrain the uncertainty of predictions of advective radionuclide transport models constructed for the Nevada Test Site (NTS). Since heat transport, hydrologic and geochemical models for a given area must all be consistent, devaluing the weight of those models that do not match estimated heat flow can reduce uncertainty.

The objective of this study was to identify the quantity and quality of available heat flow data at the NTS. Although thousands of temperature logs have been conducted at the NTS, most are recorded on paper and not easily examined. In this investigation only those temperature logs in digital format were considered.

\section{BASIC HEAT FLOW TERMS}

Temperature, $\mathrm{T}\left(\right.$ Celsius, $\left.{ }^{\circ} \mathrm{C}\right)$ provides a measurement of the free energy available at a location. This energy can be visualized as the vibration of molecules, the greater the temperature, the greater the vibration of the molecules. The vibrations of molecules with greater energy are transferred to adjacent molecules. Thus, temperature will flow through a material from locations of greater energy to areas of lower energy; this process is defined as heat conduction.

Thermal gradient, $\mathrm{G}$ (degrees $\mathrm{C}$ per meter, ${ }^{\circ} \mathrm{C} \mathrm{m}^{-1}$ ), is defined as

$$
\partial \mathrm{T} / \partial \mathrm{z}=\left(\mathrm{T}_{2}-\mathrm{T}_{1}\right) / \Delta \mathrm{z}
$$

where $T_{1}$ and $T_{2}$ are temperatures measured at two points separated by distance $\Delta z$. By convention, a positive gradient is in the direction of increasing temperature. Although usually assumed to be vertical, thermal gradient is a vector quantity, and the actual direction of the maximum thermal gradient depends on the distribution of temperature in three dimensions.

The rate of one-dimensional heat flow, Q (milliwatts per square meter, $\mathrm{mW} \mathrm{m} \mathrm{m}^{-2}$ ) between two points, within a homogeneous thermal conductivity field, is defined as

$$
\mathrm{Q}=-\lambda * \partial \mathrm{T} / \partial \mathrm{z}
$$

where, $\mathrm{Q}$ is conventionally taken to be positive in the direction of decreasing temperature, $\lambda$ is a physical property of a medium known as thermal conductivity (watts per meter per degree Celsius, $\mathrm{W} \mathrm{m}^{-1}{ }^{\circ} \mathrm{C}^{-1}$ ), which is a measure of how easily heat is transmitted through a material. As with the thermal gradient, heat flow is a vector quantity. To determine the true vector value (magnitude and direction) of heat flow, the three-dimensional temperature distribution has to be known. 
In addition to conduction, as described above, moving fluids carry heat by advection. If the direction of heat flow from conduction and advection coincide, the effect can be quantified by considering the ratio of fluid-transported heat to conducted heat. This ratio is called the Peclet number $(\mathrm{Pe})$. Conduction appears to be the dominant means by which heat is transported through the Earth's crust. A compilation of conductive heat flow measured over much of the Earth's surface suggests a global mean heat flow of approximately $87 \mathrm{~mW} \mathrm{~m}^{-2}$ (Pollack et al., 1993).

\section{Thermal Gradient}

Measurement of a thermal gradient, at a minimum, requires the determination of temperatures measured at two points separated by a known distance. However, the better defined the temperature distribution, the greater the accuracy of a thermal gradient, and therefore, heat flow can be determined.

Temperature measurements in fluid-filled boreholes are obtained by direct measurement using high-precision downhole temperature logging tools. Modern downhole temperature logging tools have resolutions of approximately $0.001^{\circ} \mathrm{C}$, however, accuracy is rarely better than $\pm 2{ }^{\circ} \mathrm{C}$ for any given logging tool. Conducting a two-point calibration before conducting the temperature log, as well as an additional twopoint calibration check following logging can enhance the accuracy of the tool. In general, a two-point calibration consists of recording the temperature tool response at two known temperatures and using this information to correct the temperatures measured by the tool during logging. Using the two-point calibration method, accuracy of a temperature tool can usually be increased to within $\pm 0.1^{\circ} \mathrm{C}$. Although accuracy is desirable, it should be noted that since we are using thermal gradients to determine heat flow, absolute accuracy of the temperature measurements is not critical.

Temperatures measured in the boreholes must be representative of actual formation temperatures outside the borehole to be used in the determination of valid heat flow values. Ideally, the borehole should be cased to prevent cross flow between aquifers penetrated by the borehole. Additionally, the annular space between the casing and the borehole should be cemented, or otherwise sealed, through the saturated portion of the borehole to prevent cross flow between aquifers in the annular space. Furthermore, sufficient time must be allowed, following construction of the borehole, for fluid within the borehole to return to thermal equilibrium with the surrounding formations.

Another factor that must be considered is convection of fluid within a borehole. Convection is the movement of water, and subsequently heat, due to a temperatureinduced difference in fluid density. Since, generally, borehole temperatures increase with depth, it would appear that the warmer waters deeper within the borehole would tend to rise up through the cooler fluids higher in the borehole, producing convection cells. Hales (1937), Auld (1948), and Diment (1967) investigated this phenomenon and developed, and refined, an equation to describe convection in boreholes relating fluid properties and the radius of the borehole to a critical thermal gradient, above which convection would be expected. Using this equation, it can shown that for normal geothermal gradients (approximately $25^{\circ} \mathrm{C} / \mathrm{km}$ ), convection can be expected in boreholes with diameters greater than about $5 \mathrm{~cm}$. However, several field investigations by Urban et al. (1978), Diment (1967), Gretener (1967) and Wisian et al. (1998), as well as the observations by 
this author, have shown that although convection cells do form, they rarely extend vertically more than a few borehole diameters before dying out. Thus, the general effect of convection within boreholes is to decrease the signal-to-noise ratio of a temperature $\log$ without interfering with broader temperature trends. For example, it would be impossible to discern minute changes in gradient produced by lithologic units with thickness smaller than a few borehole diameters, however, the overall gradient of a unit several meters thick in a borehole of several tens of centimeters in diameter could be accurately determined. Essentially, boreholes with higher thermal gradients and larger diameters produce noisier temperature logs.

\section{Thermal Conductivity}

Thermal conductivity is a measure of how easily heat is transmitted through a material and is an inherent physical property of that material. It must be noted that the thermal conductivity of a material may be anisotropic, that is, having different values for different directions through the same material.

Thermal conductivity and lithology are closely related. To determine heat flow values from a thermal gradient profile, it is essential that the thermal conductivity of the lithologies penetrated by the boreholes be determined as accurately as possible.

The thermal conductivity of a rock is a function of the composition and geometry of its constituent minerals and pore fluids. If the type, percentage volume, and thermal conductivity values of a rock's mineral constituents and pore fluids are known, the thermal conductivity of the rock may be estimated by calculating a mean of the thermal conductivity of the rock's component parts. However, this method does not account for the geometric orientation of the mineral constituents of the rock.

Ideally, each lithology in a study area should be sampled multiple times and their range of physical thermal conductivity determined in the laboratory. Once the range of thermal conductivity of the various lithologic units has been determined, it may be possible to relate various geophysical logs (primarily those that measure mineralogy and porosity) to thermal conductivity.

\section{Heat Flow}

One-dimensional heat flow, in a homogenous thermal conductivity field, is the product of two values: thermal conductivity multiplied by the thermal gradient. This applies whether the thermal gradient is measured over an interval of uniform thermal conductivity, or an average thermal gradient is measured over an interval of averaged thermal conductivity values. For purely conductive vertical heat flow under steady upper and lower boundary conditions, heat flow values will remain constant (Figure 1). Figure 1 also illustrates that a thickness-weighted harmonic mean thermal conductivity for all intervals:

$$
\lambda_{\text {avg }}=\Delta \mathrm{z} /\left[\Delta \mathrm{z}_{1} / \lambda_{1}+\Delta \mathrm{z}_{2} / \lambda_{2}+\Delta \mathrm{z}_{3} / \lambda_{3} \ldots\right]=2.66 \mathrm{~W} \mathrm{~m}^{-1}{ }^{\circ} \mathrm{C}^{-1}
$$

combined with a thermal gradient of:

$$
\mathrm{G}=\Delta \mathrm{T} / \Delta \mathrm{z}=0.023{ }^{\circ} \mathrm{C} \mathrm{m}^{-1}
$$

results in a heat flow of $0.06 \mathrm{~W} \mathrm{~m}^{-2}$. 


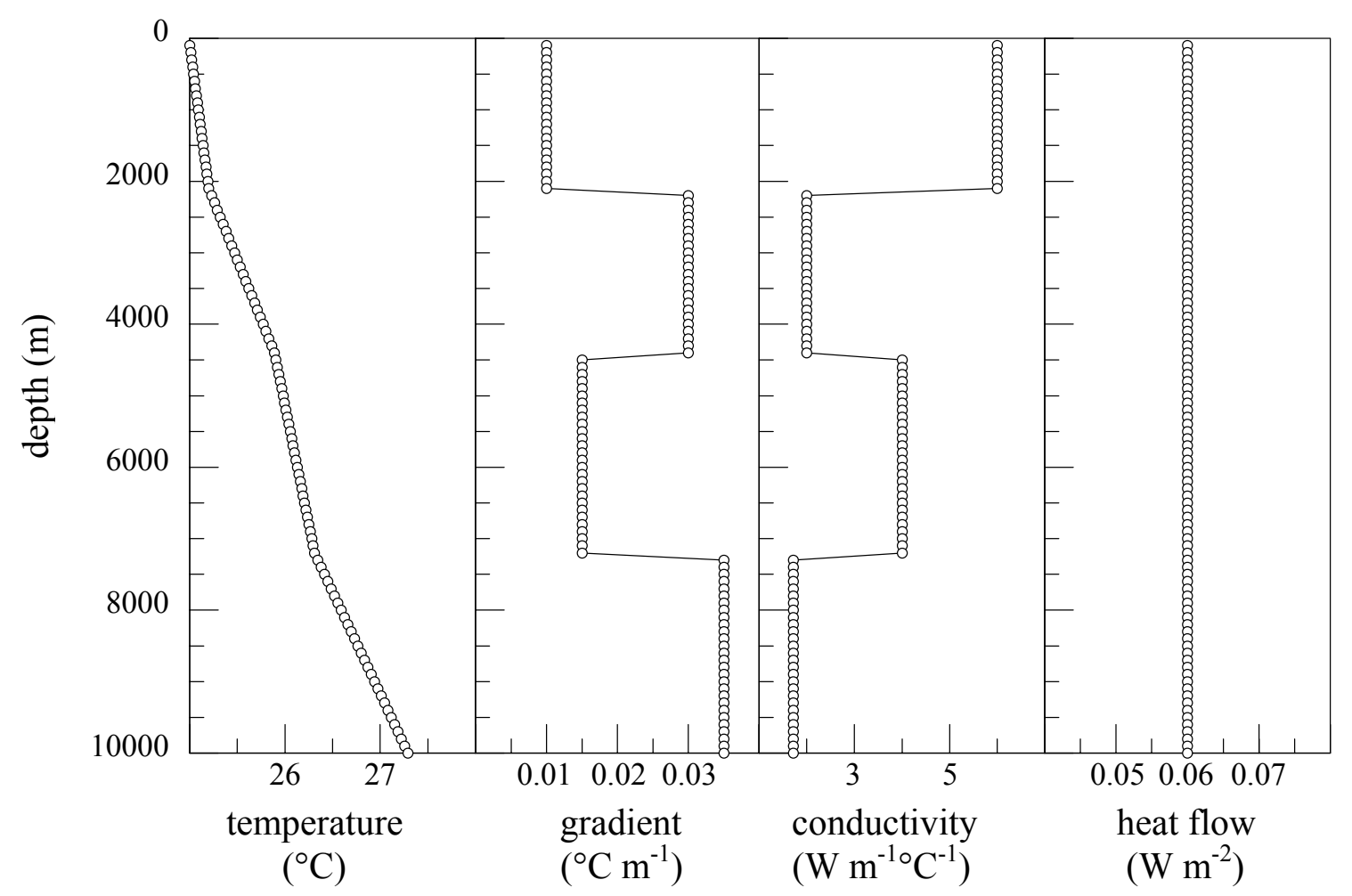

Figure 1. Relationship between temperature, thermal gradient, thermal conductivity, and heat flow in a purely conductive thermal regime.

Variations in vertical heat flow can result from many sources. Obviously, errors in temperature measurement and/or thermal conductivity values will result in erroneous heat flow values. Additionally, several thermal conditions may produce variations in vertical heat flow.

Radiogenic heat, or heat produced by radioactive decay within the rocks themselves, will produce additional heat energy within the rock unit, producing a gradual increase in the measured heat flow within the unit and greater heat flow values in adjacent rock units above relative to units below the heat-producing interval.

Climate change, sedimentation and erosion produce variations in vertical heat flow profiles by changing the upper boundary condition. Basement relief and topography produce non-horizontal surface boundaries that distort heat flow away from the vertical. Like most other forms of energy, heat generally will follow the path of least resistance. Heat will be refracted around areas of thick or low-conductivity rocks and be channeled to areas with elevated basement rock. In mountainous areas, heat preferentially flows into valleys and surface heat flow will vary with elevation.

Calculating heat flow from observed temperature gradients, assuming onedimensional conductive heat flow in a homogeneous thermal conductivity field, can result in erroneous heat flow estimates in an advectively disturbed thermal regime. 
Groundwater movement can disturb the temperature field, causing it to differ from the purely conductive case. The advective transport of heat by the vertical movement of groundwater will cause the calculated conductive heat flux to decrease or increase with elevation depending on the direction of flow. Calculated conductive heat flux will decrease with elevation in the borehole when groundwater movement is downward and vice versa. As groundwater moves horizontally through a porous rock unit, the fluid repeatedly is divided and recombined. This dispersion, or mixing, of the groundwater has the effect of lowering the thermal gradient within the rock unit without affecting the actual vertical heat flow, thus resulting in an apparent increase in the thermal conductivity of the unit. Therefore, when the actual thermal conductivity of an aquifer with horizontal flow is used to calculate heat flow, the zone would appear as an interval of low heat flow compared to those units above and below the aquifer.

\section{PREVIOUS INVESTIGATIONS}

The earliest heat flow and thermal studies (e.g., Van Orstrand, 1934; Bullard, 1939; Birch, 1947) found that purely conductive heat flow could not explain the subsurface temperature distributions observed in their investigations. Subsequent heat flow investigations (i.e., Lachenbruch et al., 1976; Reiter et al., 1979; Chapman et al., 1981) confirmed these findings and established the role of advective heat transport by groundwater in controlling subsurface thermal regimes. Smith and Chapman (1983) and Woodbury and Smith (1985) presented numerical solutions of the equations of fluid flow and heat transport to quantify the effects of groundwater flow on the subsurface thermal regime and showed that with sufficient knowledge of the complete environment of a site, including water table elevations and boundary conditions, and with adequate spacing between measurement points, advectively perturbed thermal fields could be used to infer hydraulic parameters.

In addition to investigations of the effect of advective heat transport by groundwater, recent heat flow studies have been undertaken to determine the thermal history of sedimentary basins to understand petroleum migration and maturation (Hunt et al., 1991; Lowrie et al., 1996; Lopatin et al., 1976). Investigations of the subsurface thermal regime have also recently been utilized to estimate historical climate changes as evidence of global warming (Beck, 1992; Beltrami and Taylor, 1995; Chisholm et al., 1992; Deming and Borel, 1996; Huang et al., 2000; Pollack, 1993; Whitefore, 1993).

Previous heat flow investigations at the NTS (e.g., Sass et al., 1980, 1987; Fridrich et al., 1994) have been conducted primarily in conjunction with hydrologic studies at the Yucca Mountain High-level Nuclear Waste Repository site.

Pottorff (1987) examined temperature profiles from numerous emplacement boreholes in Areas 19 and 20 at the NTS in an attempt to obtain quantitative information on the hydrologic regime of Pahute Mesa. A qualitative assessment of the logs provided useful information on static water levels and areas of water influx into the boreholes, however, Pottorff (1987) determined that the uncertain quality of the data and the effects (convection) of the large diameter of the boreholes $(25$ to $183 \mathrm{~cm})$ rendered the data of little value for quantitative hydrologic analysis.

Sass and Lachenbruch (1982) examined temperature data from 60 boreholes in and around the NTS, including 16 from the Yucca Mountain area. Sass and Lachenbruch 
(1982) determined that, based on the shape of the temperature profiles, 15 of the 60 temperature logs were usable for the determination of heat flow values (Table 1). The original digital temperature data used by Sass and Lachenbruch (1982) were obtained by the U.S. Geological Survey and were not available for review and interpretation by this author. Additionally, Sass and Lachenbruch (1982) utilized temperature data from portions of boreholes without casing in place. These borehole temperature profiles may have been influenced by vertical fluid flow within the borehole and therefore the measured gradient may not represent the actual thermal regime outside the borehole. In this study, only those portions of boreholes with casing, where vertical fluid flow within the borehole is impossible, or at least extremely unlikely, were used to determine geothermal gradients.

Table 1. Heat flow values from Sass and Lachenbruch (1982).

\begin{tabular}{lc}
\hline Well Name & Heat Flow $\left(\mathrm{mW} \mathrm{m}^{-2}\right)$ \\
\hline PM-2 & 63 \\
PM-1 & 42 \\
DOL & 80 \\
U15K & 56 \\
UE-17e & 66 \\
TW-E & 29 \\
J-13 & 67 \\
UE-25a1 & 54 \\
UE-25b1 & 47 \\
UE-25a3 & 130 \\
USWG1 & 52 \\
TW-F & 76 \\
TW-3 & 92 \\
TW-5 & 84 \\
TW-4 & 91 \\
\hline
\end{tabular}

\section{EVALUATION OF EXISTING NTS TEMPERATURE LOGS}

In this investigation, 145 temperature logs from 63 wells (Figure 2) on or near the NTS were examined. Of these 145 temperature logs, 62 were obtained from Bechtel Nevada and were run by Atlas Wireline Services. Seventeen of the temperature logs were obtained from Lawrence Livermore National Laboratory (LLNL) and were run by LLNL. The Desert Research Institute (DRI) ran the remaining 66 temperature logs.

Because it is necessary for a borehole to return to thermal equilibrium with the surrounding rock, the 145 temperature logs were ranked based on the length of time that had passed since completion of the borehole. The time required for a borehole to return to thermal equilibrium with the surrounding formations depends on several factors: The length of time taken to drill the borehole, the diameter of the borehole, the temperature 


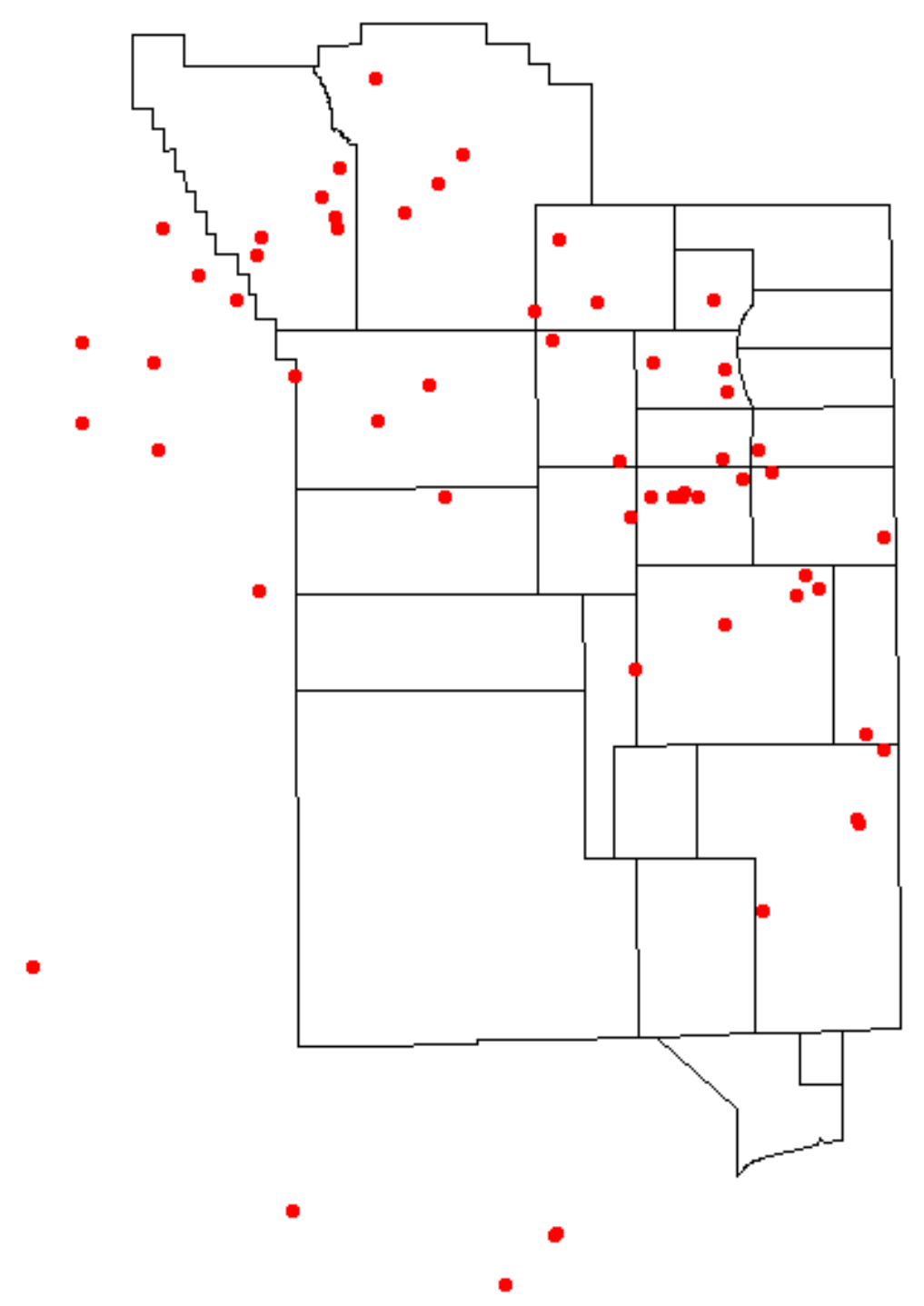

Figure 2. Location of boreholes at the NTS with temperature logs examined in this investigation.

and amount of fluids introduced to and/or removed from the borehole during construction, lithology (porosity/thermal conductivity) of the formations penetrated by the borehole, the amount and temperature of drilling fluid lost to the formations during drilling, etc. In general, at the completion of the drilling process, the upper two-thirds of the borehole has been warmed relative to the actual temperature of the surrounding formations and the lower one-third of the borehole has been cooled relative to the actual temperature of the surrounding formations. Given the wide variability of these factors, thermal equilibrium of a borehole may require days, months, years, or even decades. The only method to ensure a borehole has returned to thermal equilibrium is to obtain two 
temperature logs sufficiently separate in time to verify thermal stability of the borehole. As it will be shown later in this report, of the wells selected for analysis only one borehole was logged twice sufficiently separated in time to ensure thermal equilibrium. Therefore, a time of one year between completion of the borehole and conduction of the temperature log was somewhat arbitrarily selected as the minimum time necessary for a borehole to return to thermal equilibrium. This resulted in 88 temperature logs that were obtained less than one year after borehole completion; seven temperature logs were obtained between one and two years since their boreholes were completed; and 41 of the temperature logs were conducted more than two years after their boreholes were completed. Two of the temperature logs did not include information indicating the date on which the logs were obtained. The remaining seven temperature logs were obtained in emplacement holes with borehole diameters large enough, and/or with logged intervals short enough, to have rendered the data questionable due to the possible presence of convection cells.

Construction information (depth of casing, presence of slotted casing or perforations, etc.) for the 39 boreholes logged one year or more after the completion of drilling was assembled and evaluated to eliminate those boreholes where vertical flow within the borehole might be present. Also eliminated were those boreholes with temperature profiles too short relative to the borehole diameter to yield accurate heat flow values. Additionally, one borehole, ER-6-1S, was determined to be located approximately $15 \mathrm{~m}$ from borehole ER-6-1 in which drilling activity was conducted 6 months prior to temperature logging at ER-6-1S. Since drilling activity at ER-6-1 may have impacted the temperature profile at ER-6-1S, ER-6-1S was also excluded from consideration. A total of 13 boreholes were determined to have temperature profiles suitable for the determination of heat flow values.

\section{HEAT FLOW VALUES FOR NTS WELLS WITH SUITABLE TEMPERATURE DATA}

To determine heat flow values from temperature profiles, the thermal conductivity of the lithologies penetrated by the borehole must be known. Sass et al. (1987) measured thermal conductivities of 135 specimens of volcanic tuffs and 13 specimens of Paleozoic carbonate obtained from core samples retrieved from saturated portions of boreholes drilled at the Yucca Mountain Site (Figure 3 and Table 2).

Average thermal conductivity for the volcanic tuff lithologies measured by Sass et al. (1987) was $1.72 \pm 0.03 \mathrm{~W} \mathrm{~m}^{-1}{ }^{\circ} \mathrm{C}^{-1}$. For the 13 specimens of Paleozoic carbonate lithology, an average thermal conductivity of $5.0 \mathrm{~W} \mathrm{~m}^{-1}{ }^{\circ} \mathrm{C}^{-1}$ was determined. It should be noted that given the relatively small number of samples of each lithology, together with the marked similarity of the mean values and standard deviation between 0.1 and 0.5 show that many of the mean values are not statistically different. For example, the mean value for the welded tuff and mod-welded tuff are not statistically different. However, a definite trend in increasing thermal conductivity with increased density of welding is readily observable.

Johnston et al. (1981) and Wright and Louden (1989) as well as others have published thermal conductivity values for various rock types (Tables 3 and 4). 


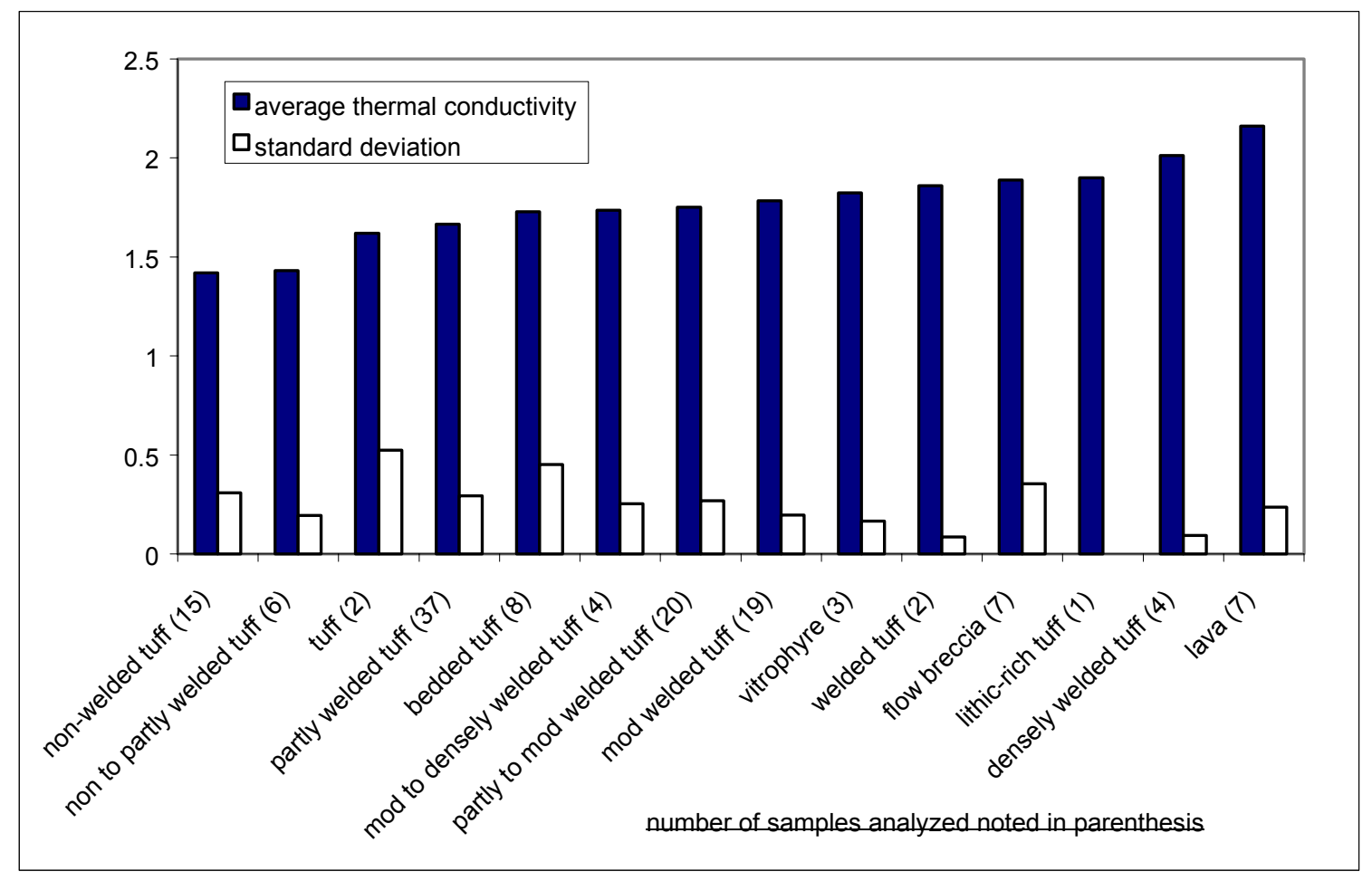

Figure 3. Laboratory measured thermal conductivity values $\left(\mathrm{W} \mathrm{m}^{-1 \circ} \mathrm{C}^{-1}\right)$ for Tertiary volcanic lithologies, Sass et al. (1987).

Table 2. Thermal conductivity of major volcanic rock types at the NTS from Sass et al., (1987).

\begin{tabular}{lccccc}
\hline Lithology Type & $\begin{array}{c}\text { Thermal } \\
\text { Conductivity } \\
\text { minimum }\end{array}$ & $\begin{array}{c}\text { Thermal } \\
\text { Conductivity } \\
\text { average }\end{array}$ & $\begin{array}{c}\text { Thermal } \\
\text { Conductivity } \\
\text { maximum }\end{array}$ & $\begin{array}{c}\text { Number of } \\
\text { Samples }\end{array}$ & $\begin{array}{c}\text { Standard } \\
\text { Deviation }\end{array}$ \\
\hline non-welded tuff & 1.06 & 1.42 & 2.1 & 15 & 0.3092 \\
non to partly welded tuff & 1.23 & 1.43 & 1.73 & 6 & 0.1936 \\
tuff & 1.25 & 1.62 & 1.99 & 2 & 0.5232 \\
partly welded tuff & 1.19 & 1.66 & 2.31 & 37 & 0.2931 \\
bedded tuff & 1.1 & 1.73 & 2.42 & 8 & 0.4515 \\
mod to densely welded tuff & 1.36 & 1.73 & 1.9 & 4 & 0.2537 \\
partly to mod welded tuff & 1.37 & 1.75 & 2.26 & 20 & 0.2681 \\
mod welded tuff & 1.37 & 1.78 & 2.21 & 19 & 0.1967 \\
vitrophyre & 1.67 & 1.82 & 2 & 3 & 0.1662 \\
welded tuff & 1.8 & 1.86 & 1.92 & 2 & 0.0848 \\
flow breccia & 1.43 & 1.89 & 2.46 & 7 & 0.3536 \\
lithic-rich tuff & 1.9 & 1.9 & 1.9 & 1 & NAN \\
densely welded tuff & 1.94 & 2.01 & 2.15 & 4 & 0.0936 \\
lava & 1.77 & 2.16 & 2.49 & 7 & 0.2360 \\
dolomite & 4.45 & 4.95 & 5.47 & 13 & 0.2848 \\
\hline
\end{tabular}


Table 3. Typical rock thermal conductivity values from Wright and Louden (1989).

\begin{tabular}{cc}
\hline Rock Types & Thermal Conductivity $\left(\mathrm{W} \mathrm{m}^{-1 \circ} \mathrm{C}^{-1}\right)$ \\
\hline All mudstones & 1.85 \\
Calcium mudstones & 1.76 \\
Silty mudstones & 2.15 \\
Siltstone & 1.91 \\
Muddy sandstones & 2.23 \\
All sandstones & 2.92 \\
Quartz sandstone & 5.09 \\
All limestones & 2.51 \\
Dolomite & 4.78 \\
\hline
\end{tabular}

Table 4. Typical rock thermal conductivity values from Johnston et al. (1981).

\begin{tabular}{lc}
\hline \multicolumn{1}{c}{ Rock Types } & Thermal Conductivity $\left(\mathrm{W} \mathrm{m}^{-1 \circ} \mathrm{C}^{-1}\right)$ \\
\hline Shale & 1.5 \\
Evaporites & 5.4 \\
Limestone & 1.3 to 5.0 \\
Dolomite & 5 \\
Sandstone & 1.8 to 4.2 \\
Schist & 1.6 \\
Gneiss & 2.5 \\
Greenstone & 3.3 \\
Slate & 3.8 \\
Argillite & 3.3 \\
Quartzite & 4.5 to 7.1 \\
Granite & 1.7 to 4.0 \\
Diabase & 2.1 \\
Gabbro & 2.5 \\
Granodiorite & 2.6 \\
\hline
\end{tabular}

Utilizing published thermal conductivity values (Table 4) and measured geothermal gradients, heat flow values were determined for the 13 boreholes (Figure 4) with temperature logs deemed suitable due to construction, and for which it appeared a sufficient duration of time had passed from when the log was run to when the borehole was completed. 


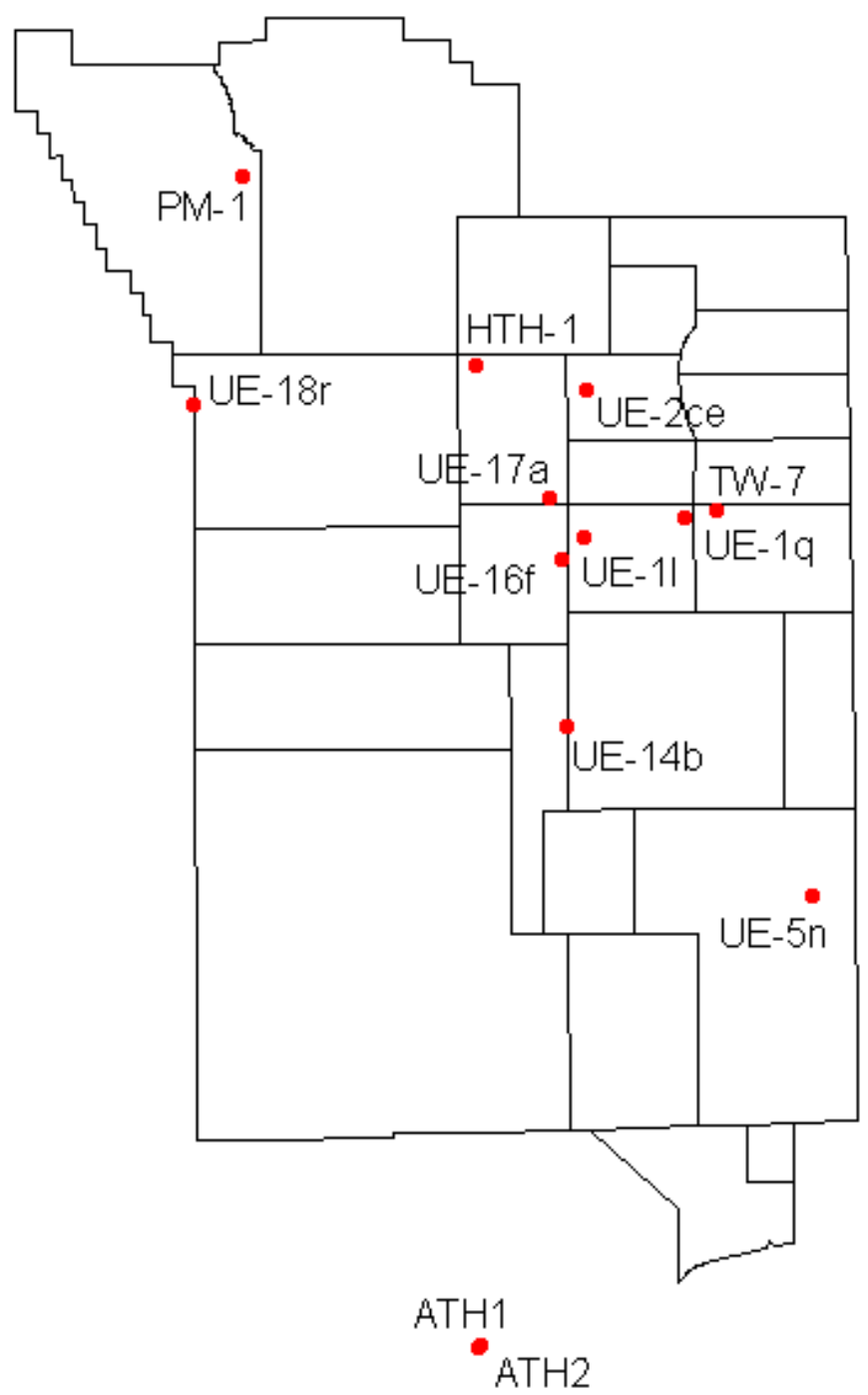

Figure 4. Location of boreholes on, or near, the NTS with temperature profiles suitable for calculation of heat flow values.

Following is a discussion of each of the 13 boreholes for which heat flow values were calculated. Included with the discussion of each well is an illustration displaying the temperature vs. depth profile from each well, the lithology penetrated by the borehole, and the borehole construction.

UE-1q

UE-1q was first completed in May 1980. The borehole was subsequently recompleted by deepening, to a total depth of $792.48 \mathrm{~m}$ below ground surface and placement of 27.3-cm-diameter casing in May 1992. The temperature profile used in calculation of heat flow values for this borehole was conducted by DRI on July 19, 1994. 
As shown in Figure 5, the contact between the Tertiary tuff units and the Paleozoic carbonate aquifer occurs at a depth of $710.8 \mathrm{~m}$ below ground surface. The casing was cemented within the borehole to a depth of $749.5 \mathrm{~m}$ below ground surface.

The temperature profile from borehole UE-1q displays a pronounced break in the geothermal gradient coincident with the volcanic tuff/carbonate contact at a depth of 710 $\mathrm{m}$

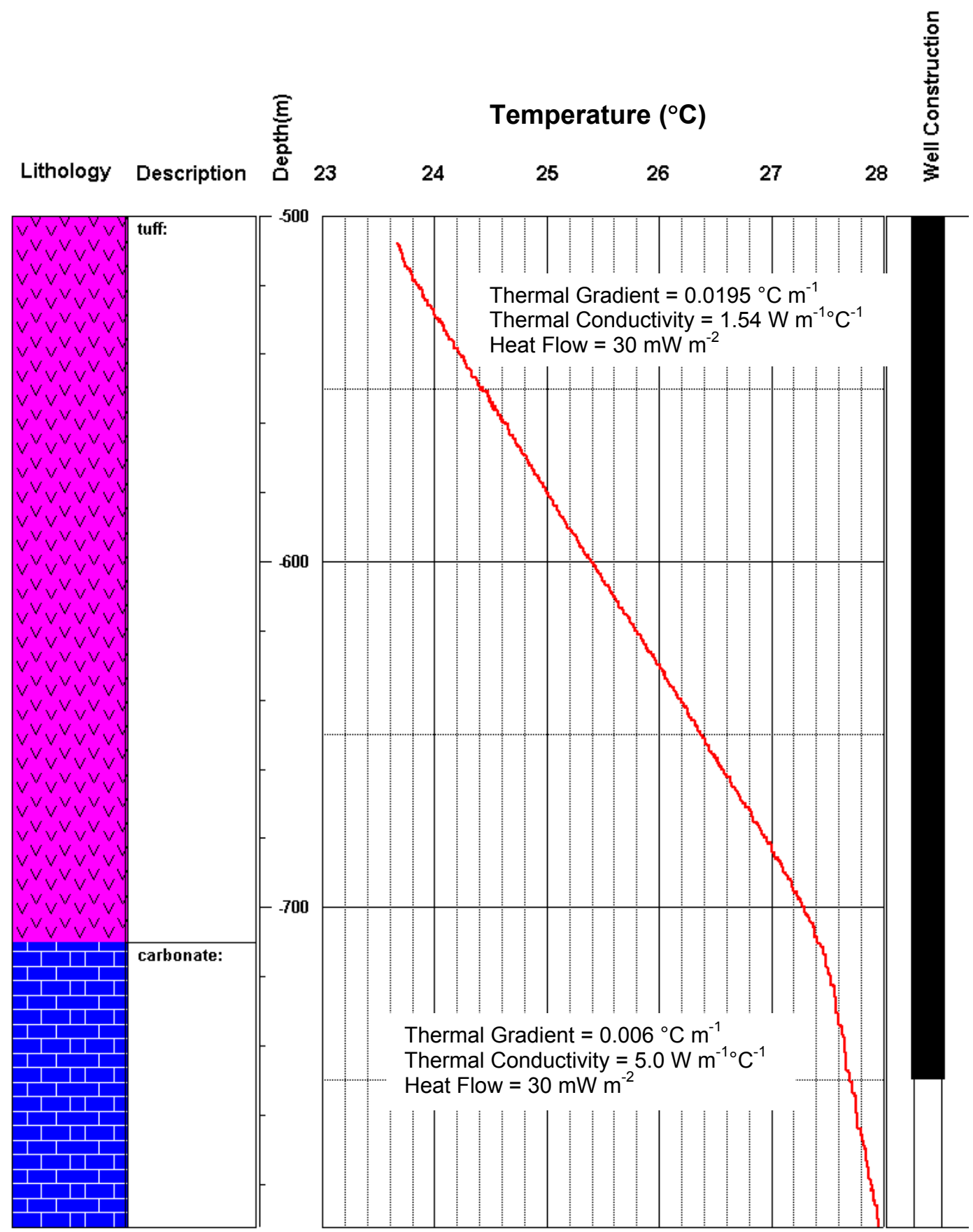

Figure 5. Temperature profile, lithology and well construction for borehole UE-1q. 
below ground surface. A least-squares fit through the portion of the temperature profile measured in the Tertiary tuff lithologies penetrated by UE-1q yields a geothermal gradient of $0.0195{ }^{\circ} \mathrm{C} \mathrm{m}^{-1}$. A least-squares fit through the portion of the temperature profile measured in the carbonate lithology above the base of the casing within UE-1q yields a geothermal gradient of $0.006{ }^{\circ} \mathrm{C} \mathrm{m}^{-1}$. The tuff units penetrated by UE-1q are comprised primarily of non-welded and bedded tuff units. Assigning a thermal conductivity of $1.54 \mathrm{~W} \mathrm{~m} \mathrm{~m}^{-10} \mathrm{C}^{-1}$ for the Tertiary units and $5.0 \mathrm{~W} \mathrm{~m}^{-1{ }^{\circ}} \mathrm{C}^{-1}$ for the carbonate lithology, heat flow values for both are approximately $30 \mathrm{~mW} \mathrm{~m}^{-2}$.

UE-18r

UE-18r (Figure 6) was completed on August 6, 1968, to a depth of $1525.2 \mathrm{~m}$ below ground surface. Casing, $27.3 \mathrm{~cm}$ in diameter, was cemented in the borehole to a depth of $496.5 \mathrm{~m}$ below ground surface. Depth to static water level in the well is $416 \mathrm{~m}$ below ground surface, resulting in approximately $80 \mathrm{~m}$ of fluid above the bottom of the casing in the borehole. The saturated portion of the borehole above the bottom of the casing is located entirely within a unit of non-welded tuff.

A least-squares regression of the linear portion of the temperature profile above the base of the casing within the borehole yielded a geothermal gradient of $0.0175{ }^{\circ} \mathrm{C} \mathrm{m}^{-}$ ${ }^{1}$. Using a thermal conductivity of $1.42 \mathrm{~mW} \mathrm{~m}^{-1 \circ} \mathrm{C}^{-1}$ (Sass et al., 1987) combined with the measured thermal gradient, results in a heat flow value of $24.8 \mathrm{~mW} \mathrm{~m}^{-2}$.

The temperature profile from UE-18r is remarkable for two additional reasons. First, an examination of the temperature profile indicates downward flow in the open borehole below the casing. This downward fluid flow is apparent from the deflection of the temperature profile. Fluid entering the borehole below the casing carries heat energy downward, masking the true thermal gradient and decreasing the apparent thermal gradient. At approximately $610 \mathrm{~m}$ below ground surface the temperature in the borehole increases rapidly, increasing the apparent thermal gradient, indicating other fluids are entering the borehole and continuing to move downward along with the fluid from above as indicted by the sharp decrease in apparent thermal gradient below $610 \mathrm{~m}$.

Second, UE-18r is the only borehole in this investigation where two temperature logs are available, sufficiently separated in time, to verify the thermal stability of the borehole. Figure 7 shows thermal profiles for UE-18r conducted by Atlas Wireline Services on March 13, 1993 and by DRI on August 31, 1994. With the exception of approximately $1.6{ }^{\circ} \mathrm{C}$ difference between the absolute temperature values measured by the logs, the temperature profiles are remarkably similar. A cross plot of temperature values between 425 and $496 \mathrm{~m}$ below ground surface of the two logs (Figure 8) yields a correlation coefficient of 0.9995 , indicating an excellent correlation between the two temperature profiles over the portion of interest in the borehole. 


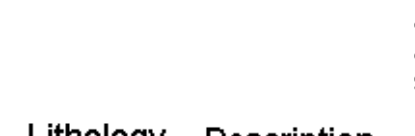

尔

Temperature $\left({ }^{\circ} \mathrm{C}\right)$
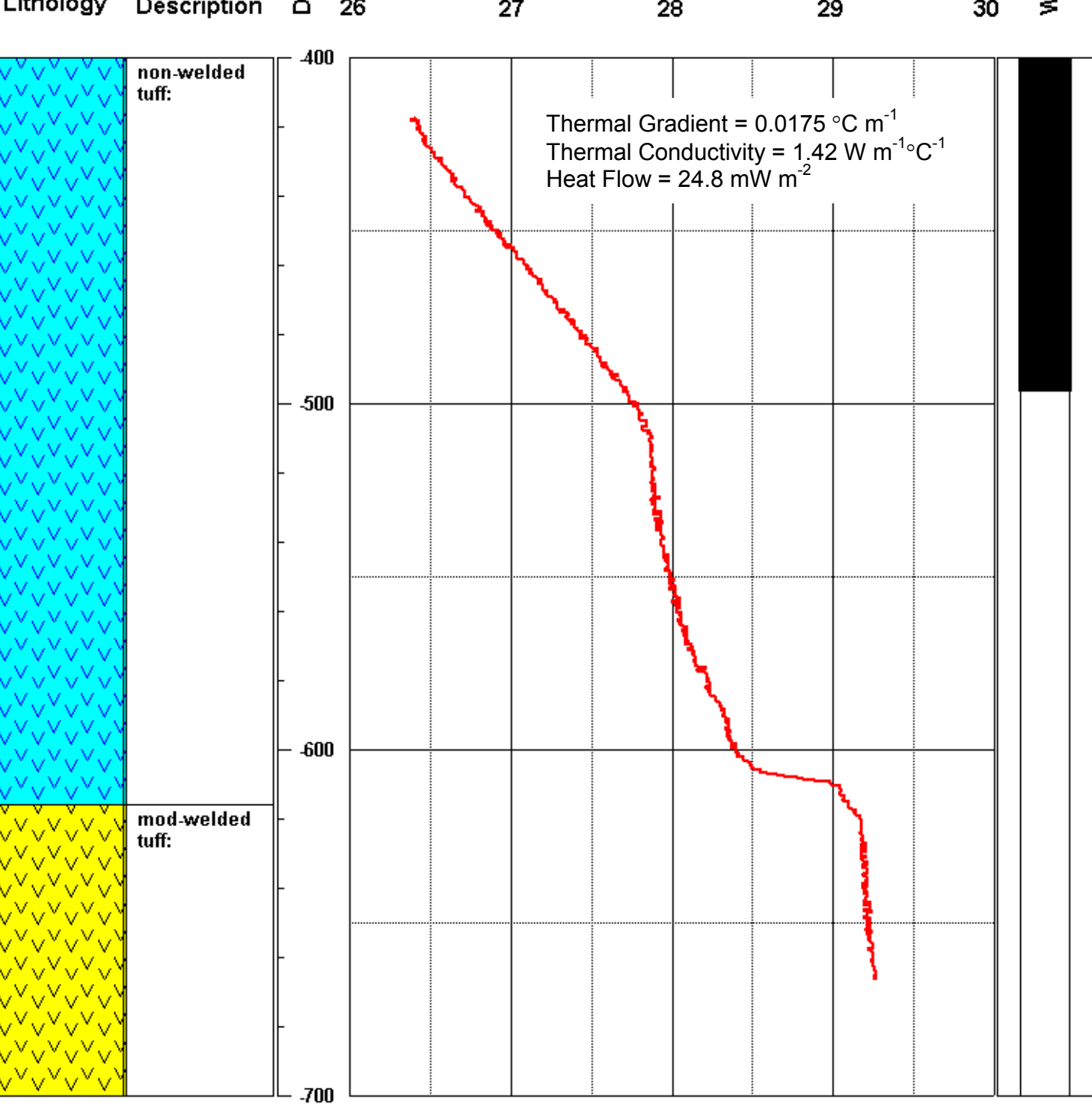

Figure 6. Temperature profile, lithology, and well construction for borehole UE-18r. 


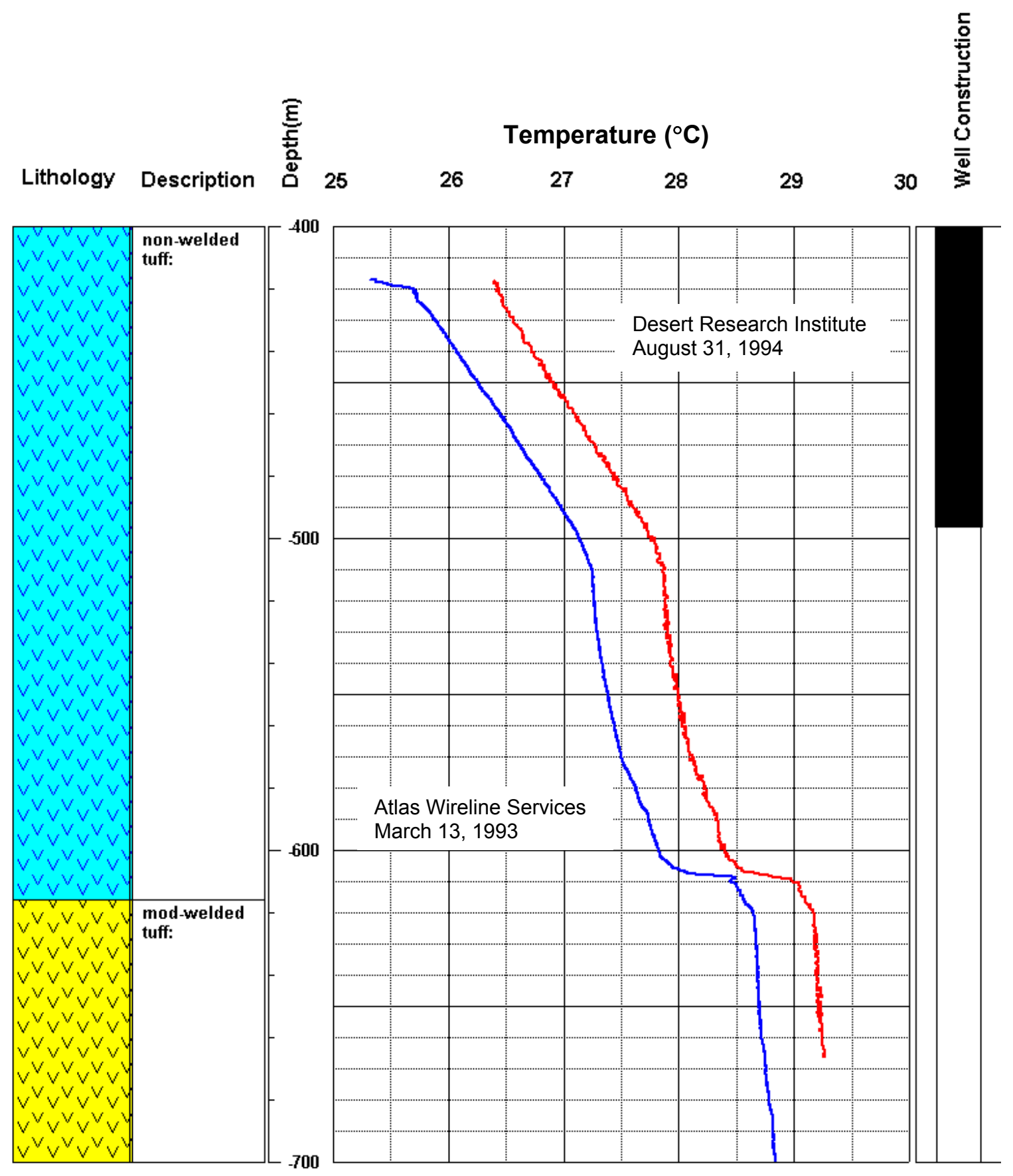

Figure 7. Comparison of temperature logs from UE-18r obtained by Atlas Wireline Services on March 13, 1993 and DRI on August 31, 1994. 


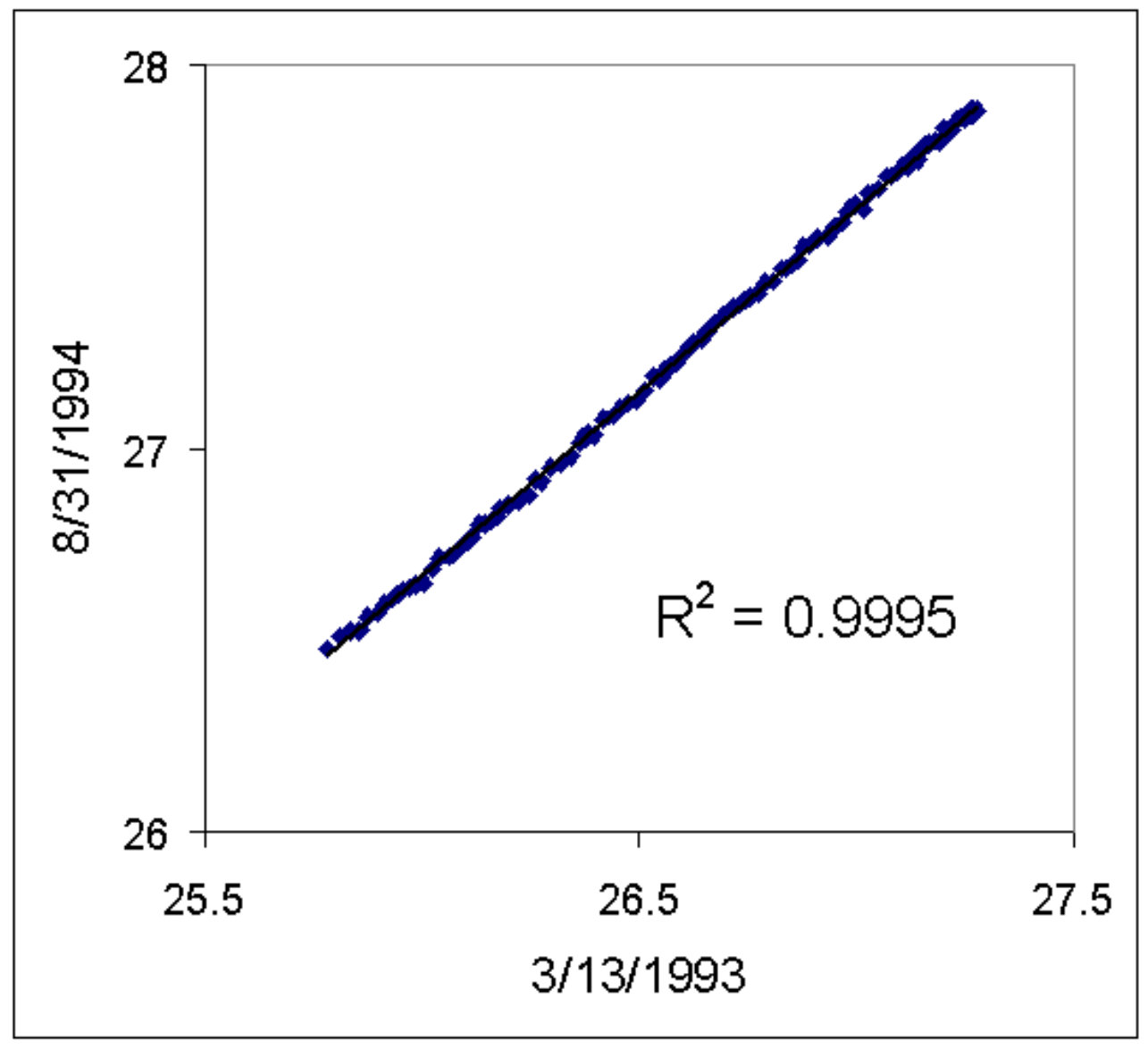

Figure 8. Cross plot of temperature values between 425 and $496 \mathrm{~m}$ below ground surface obtained in UE-18r approximately 1 year and 5 months apart.

$\mathrm{UE}-14 \mathrm{~b}$

UE-14b (Figure 9) was completed on January 1, 1984, to a depth of 1,121.7 m below ground surface. Casing, $33.97 \mathrm{~cm}$ in diameter, was cemented in the borehole to a depth of $625.1 \mathrm{~m}$ below ground surface. Depth to static water level in the well is $508 \mathrm{~m}$ below ground surface resulting in approximately $117 \mathrm{~m}$ of fluid above the bottom of the casing in the borehole. The saturated portion of the borehole above the bottom of the casing is located almost entirely within a unit of welded tuff.

DRI obtained the temperature profile from UE-14b on August 21, 1991. A leastsquares regression of the linear portion of the temperature profile from the top of the welded tuff unit, at $521.2 \mathrm{~m}$ below ground surface, to the base of the casing within the borehole yielded a geothermal gradient of $0.0124{ }^{\circ} \mathrm{C} \mathrm{m}^{-1}$. Using a thermal conductivity of $1.86 \mathrm{~W} \mathrm{~m}^{-1}{ }^{\circ} \mathrm{C}^{-1}$ (Sass et al., 1987), combined with the measured thermal gradient, results in a heat flow value of $23.1 \mathrm{~mW} \mathrm{~m}^{-2}$.

Additional features of interest in the temperature profile from UE-14b include the pronounced change in gradient at approximately $634.6 \mathrm{~m}$ below ground surface, which coincides with the contact between the welded tuff and the underlying moderately welded tuff. As published by Sass et al. (1987), moderately welded tuff has a thermal conductivity of $1.78 \mathrm{~W} \mathrm{~m}^{-1 \circ} \mathrm{C}^{-1}$, compared to the thermal conductivity of $1.86 \mathrm{~W} \mathrm{~m}^{-1 \circ} \mathrm{C}^{-1}$ 
for welded tuff. Although, as mentioned previously, the two values are not statistically different; assuming there is no vertical flow within this portion of the borehole, this decrease in thermal conductivity associated with a decrease in density of welding could account for the increase in thermal gradient measured in the temperature profile. Also, the presence of downward vertical flow within the borehole is readily apparent between approximately 700 and $770 \mathrm{~m}$ below ground surface. Downward flow within the borehole produces the typical concave upward signature seen in the temperature profile.
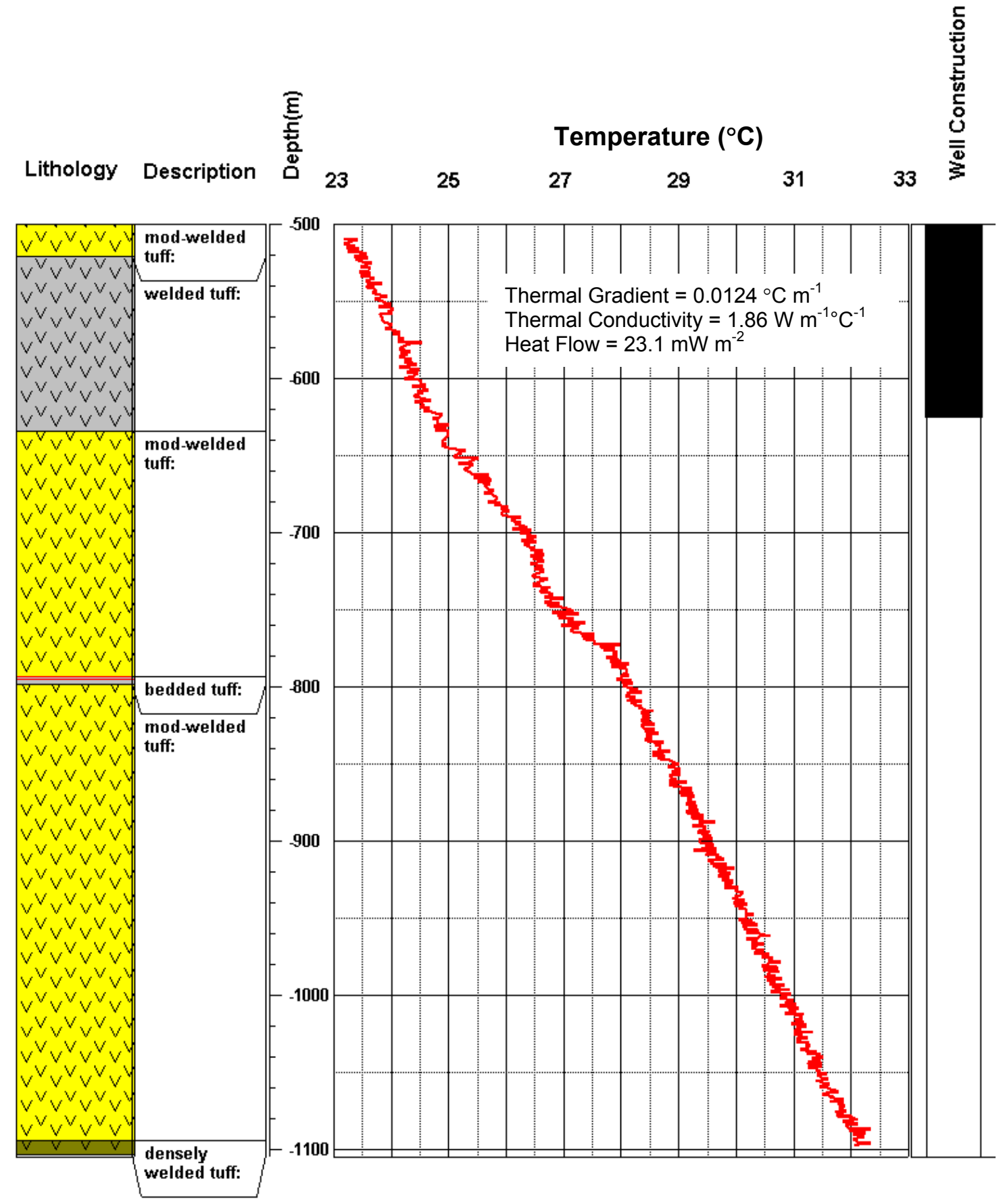

Figure 9. Temperature profile, lithology, and well construction for borehole UE-14b. 


\section{HTH-1}

HTH-1 (Figure 10) was originally completed on June 10, 1961, and subsequently recompleted on August 20, 1962. HTH-1 was drilled to a depth of 1,282 m below ground surface. Casing, $27.94 \mathrm{~cm}$ in diameter, was cemented in the borehole to a depth of 475.89 $\mathrm{m}$ below ground surface. Below the 27.94-cm-diameter casing, 20.32-cm-diameter casing was placed to a depth of $1,131.11 \mathrm{~m}$ below ground surface. This 20.32-cm-diameter casing was perforated over five intervals between the depths of $582.17 \mathrm{~m}$ and $740.66 \mathrm{~m}$ below ground surface. Depth to static water level in the well is $447 \mathrm{~m}$ below ground surface resulting in approximately $135 \mathrm{~m}$ of fluid above the top of the uppermost perforated interval in the borehole. The saturated portion of the borehole above the bottom of the casing is located almost entirely within a unit of volcanic tuff.

DRI obtained the temperature profile from HTH-1 on August 19, 1991. A leastsquares regression of the linear portion of the temperature profile above the top of the uppermost perforated interval yielded a geothermal gradient of $0.0176{ }^{\circ} \mathrm{C} \mathrm{m}^{-1}$. Using a thermal conductivity of $1.62 \mathrm{~W} \mathrm{~m}^{-1}{ }^{\circ} \mathrm{C}^{-1}$ (Sass et al., 1987), combined with the measured thermal gradient, results in a heat flow value of $28.5 \mathrm{~mW} \mathrm{~m}^{-2}$.

The extremely low-gradient portions of the temperature profile from $\mathrm{HTH}-1$ within the interval containing perforations appear to indicate the presence of vertical flow within the borehole between the perforated intervals. Although difficult to interpret, the temperature profile from HTH-1 appears to indicate the flow within the borehole to be generally downward from the upper perforated interval to the lower perforated interval.

TW-7

TW-7 (Figure 11) was completed on June 30, 1954, to a depth of $692.5 \mathrm{~m}$ below ground surface. Casing, $30.48 \mathrm{~cm}$ in diameter, was cemented in the borehole to a depth of $613.9 \mathrm{~m}$ below ground surface. Depth to static water level in the well is $499.6 \mathrm{~m}$ below ground surface resulting in approximately $114 \mathrm{~m}$ of fluid above the bottom of the casing in the borehole. The saturated portion of the borehole above the bottom of the casing is located almost entirely within a unit of volcanic tuff.

The temperature profile for TW-7 was conducted by DRI on March 20, 1996, and terminated at 601.8 below ground surface, $12.1 \mathrm{~m}$ above the base of the casing at 613.9 $\mathrm{m}$. A least-squares regression of the linear portion of the temperature profile yielded a geothermal gradient of $0.0121{ }^{\circ} \mathrm{C} \mathrm{m}^{-1}$. Using a thermal conductivity of $1.62 \mathrm{~W} \mathrm{~m}^{-1} \mathrm{C}^{-1}$ (Sass et al., 1987), combined with the measured thermal gradient, results in a heat flow value of $19.6 \mathrm{~mW} \mathrm{~m}^{-2}$.

UE-5n

UE-5n (Figure 12) was originally completed on July 1, 1976, to a depth of 514.2 $\mathrm{m}$ below ground surface. Casing, $25.4 \mathrm{~cm}$ in diameter, was cemented in the borehole to a depth of $464.2 \mathrm{~m}$ below ground surface; however, the wiper plug used to push the cement out the bottom of the casing was never drilled out, effectively sealing the bottom of the casing string. The casing was perforated between the depths of $219.5 \mathrm{~m}$ and $222.5 \mathrm{~m}$ below ground surface. Depth to static water level in the well is $214.5 \mathrm{~m}$ below ground surface. The saturated portion of the borehole is located entirely within a unit of volcanic tuff. 

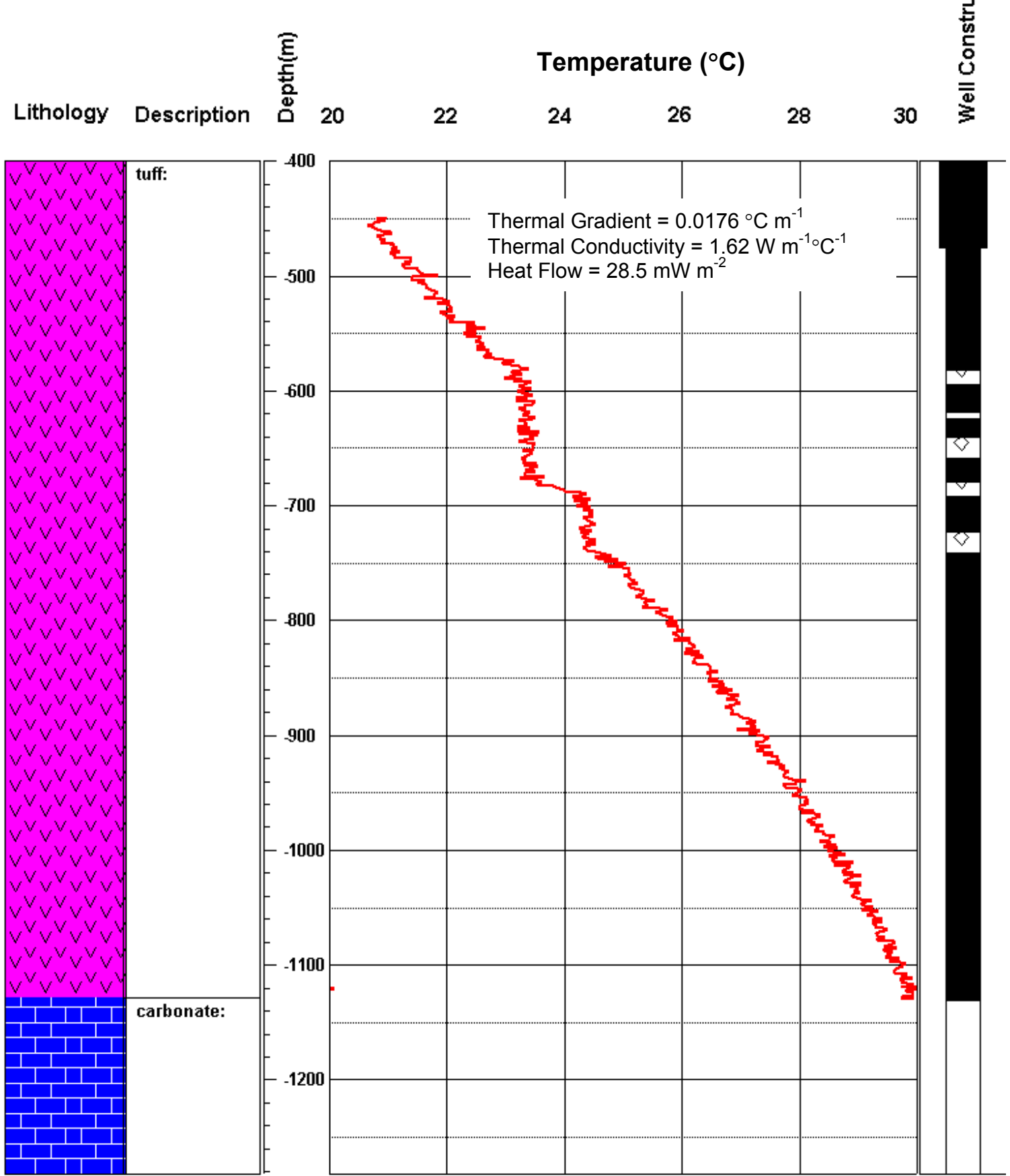

Figure 10. Temperature profile, lithology, and well construction for borehole HTH-1. 

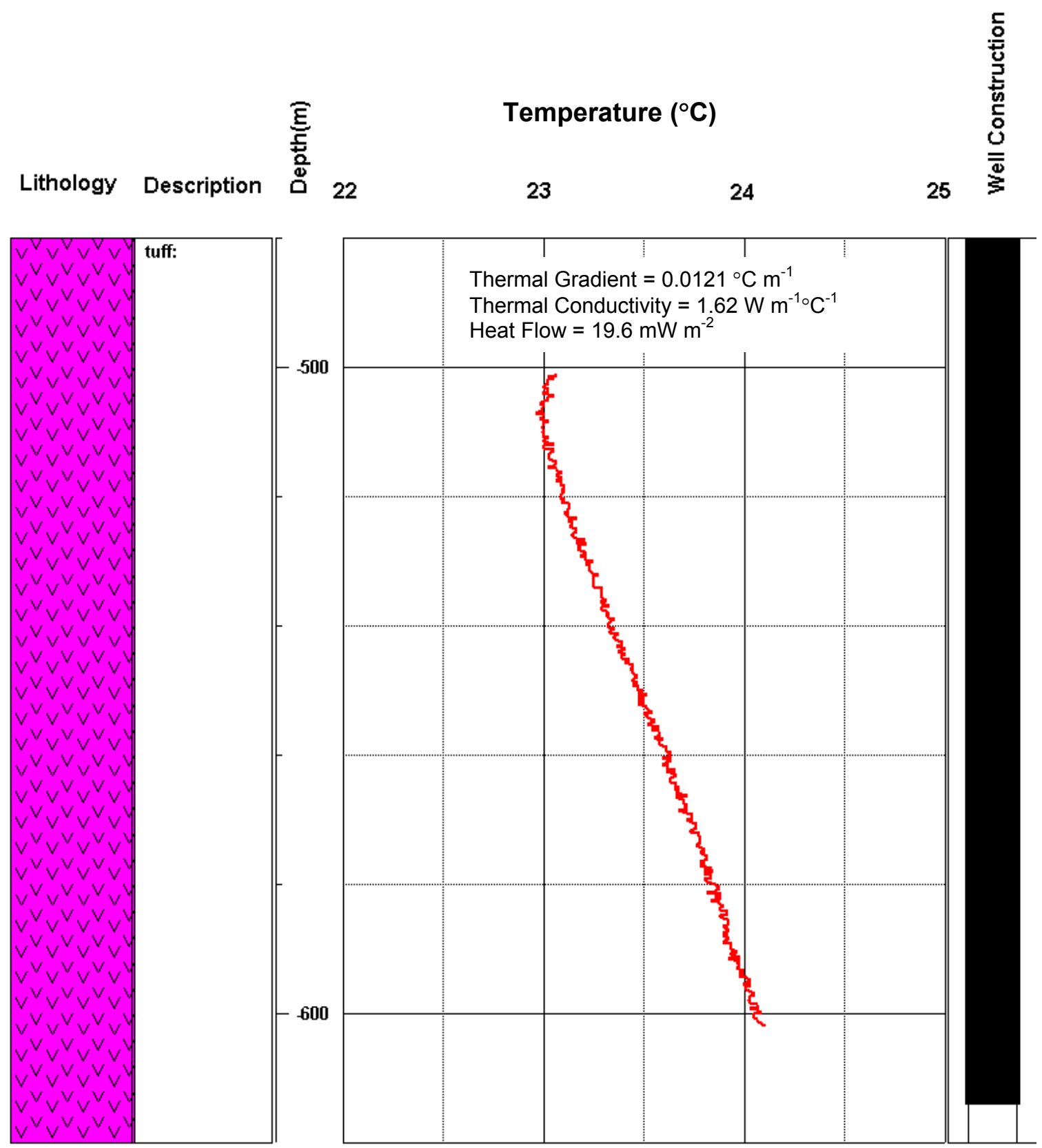

Figure 11. Temperature profile, lithology, and well construction for borehole TW-7. 

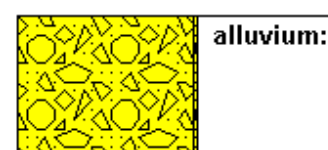

$\therefore$
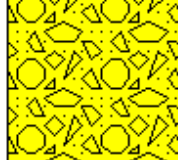

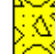

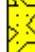

.

$\vdots$

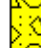

$\therefore$

:

\section{$\therefore$}

\section{0}
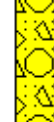

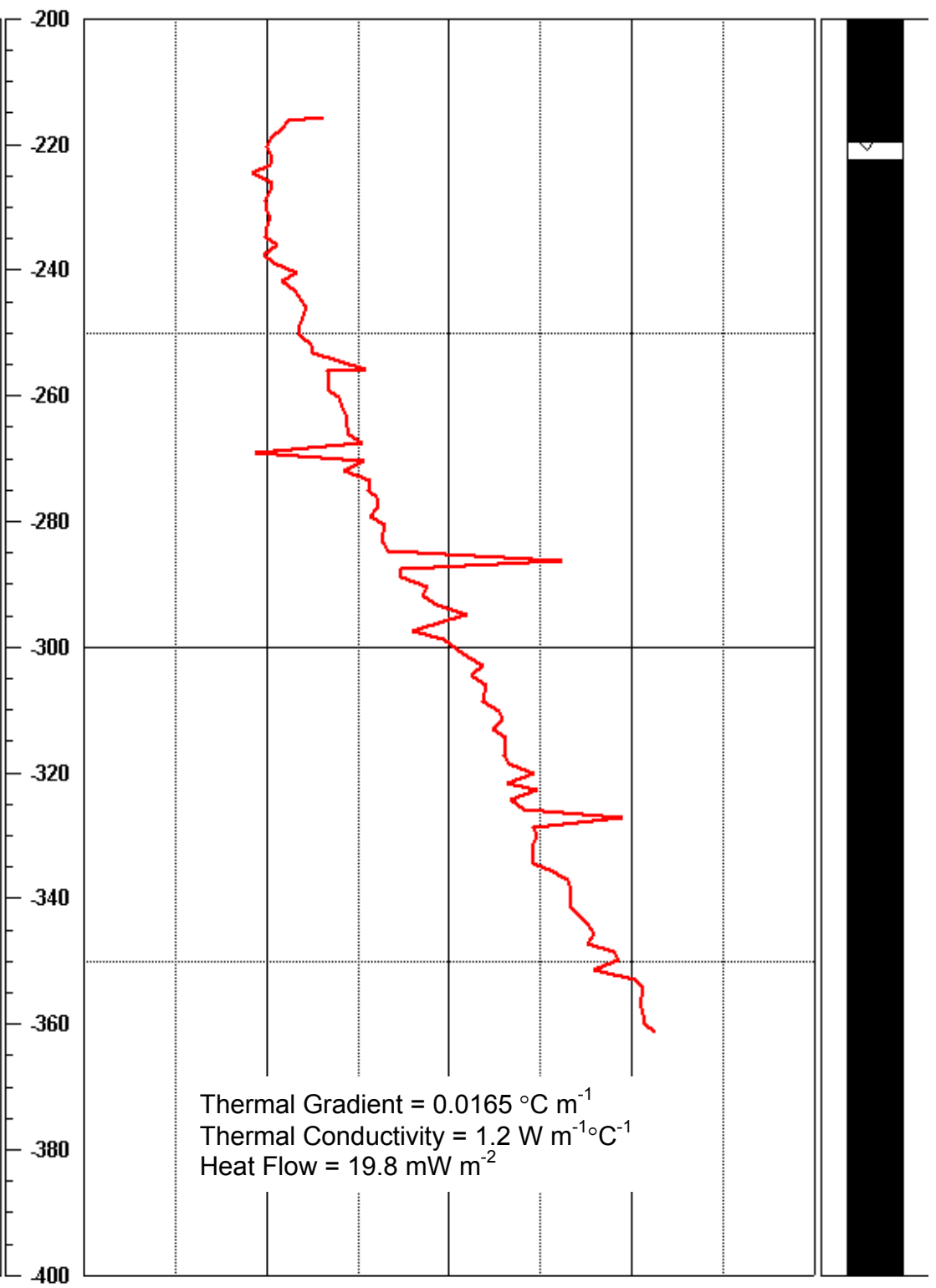

Figure 12. Temperature profile, lithology, and well construction for borehole UE-5n.

DRI conducted the temperature profile from UE-5n on July 23, 1992. The temperature log could not be completed below approximately $361 \mathrm{~m}$ below ground surface because of an obstruction in the borehole. A least-squares regression of the linear portion of the temperature profile above the obstruction yielded a geothermal gradient of 
$0.0165{ }^{\circ} \mathrm{C} \mathrm{m}^{-1}$. Using a thermal conductivity of $1.2 \mathrm{~W} \mathrm{~m}^{-1} \circ \mathrm{C}^{-1}$, combined with the measured thermal gradient, results in a heat flow value of $19.8 \mathrm{~mW} \mathrm{~m}^{-2}$.

PM-1

PM-1 (Figure 13) was completed on June 21, 1963, and recompleted on May 5, 1964, to a depth of 2,395.0 m below ground surface. Casing, $27.3 \mathrm{~cm}$ in diameter, was cemented in the borehole to a depth of 2,299.1 m below ground surface. Depth to static water level in the well is approximately $640 \mathrm{~m}$ below ground surface, resulting in approximately $1,659.1 \mathrm{~m}$ of fluid above the bottom of the casing in the borehole. The saturated portion of the borehole above the bottom of the casing is located within interbedded units of volcanic tuff of various thickness.

DRI conducted the temperature profile from PM-1 on August 3, 1994. The temperature log could not be completed below approximately $1,067.4 \mathrm{~m}$ below ground surface because of the limited length (approximately 1,067 m) of DRI's geophysical wireline.

The temperature profile from borehole PM-1 displays a small, but significant, change in the geothermal gradient coincident with the bedded tuff/non-welded tuff contact at a depth of $964.4 \mathrm{~m}$ below ground surface. The harmonic mean of the thermal conductivities (Sass et al., 1987) of the volcanic units encountered by the borehole between the static water level in the borehole and the contact between the bedded tuff and non-welded tuff units located at a depth of $964.4 \mathrm{~m}$ below ground surface was calculated to yield a composite thermal conductivity of $1.78 \mathrm{~W} \mathrm{~m}^{-1}{ }^{\circ} \mathrm{C}^{-1}$. The average geothermal gradient over this interval is $0.0245^{\circ} \mathrm{C} \mathrm{m}^{-1}$, resulting in a heat flow value of $43.6 \mathrm{~W} \mathrm{~m}^{-2}$.

A least-squares regression of the linear portion of the temperature profile below the lithologic contact at $964.4 \mathrm{~m}$ below ground surface yielded a geothermal gradient of $0.0307{ }^{\circ} \mathrm{C} \mathrm{m}^{-1}$. Using a thermal conductivity of $1.42 \mathrm{~W} \mathrm{~m}^{-1}{ }^{\circ} \mathrm{C}^{-1}$ (Sass et al., 1987), combined with the measured thermal gradient, results in a heat flow value of $43.6 \mathrm{~W} \mathrm{~m}^{-2}$, identical to the heat flow estimated in the overlying units. This vertical correlation in heat flow estimates appears to be somewhat fortuitous given the uncertainty (possible variability) in thermal conductivities of the units. Additionally, although fracture flow of groundwater might be expected within the two, relatively thin, rhyolite units located at approximately 800 and $900 \mathrm{~m}$ below ground surface, no significant deviations in the thermal gradient are detectable. Due to the limited thickness, 19.8 and $13.7 \mathrm{~m}$, respectively, for the upper and lower units, these rhyolites may not be areally contiguous and contain stagnant groundwater. It may also be that temperature profiles may not be able to distinguish variations in gradient over relatively thin lithologic units.

UE-11

UE-11 (Figure 14) was completed on August 12, 1972, to a depth of $693.4 \mathrm{~m}$ below ground surface. Casing, $33.97 \mathrm{~cm}$ in diameter, was cemented in the borehole to a depth of $218.2 \mathrm{~m}$ below ground surface. Depth to static water level in the well is $157.3 \mathrm{~m}$ below ground surface resulting in approximately $60 \mathrm{~m}$ of fluid above the bottom of the casing in the borehole. The saturated portion of the borehole above the bottom of the casing is located entirely within an argillite. 


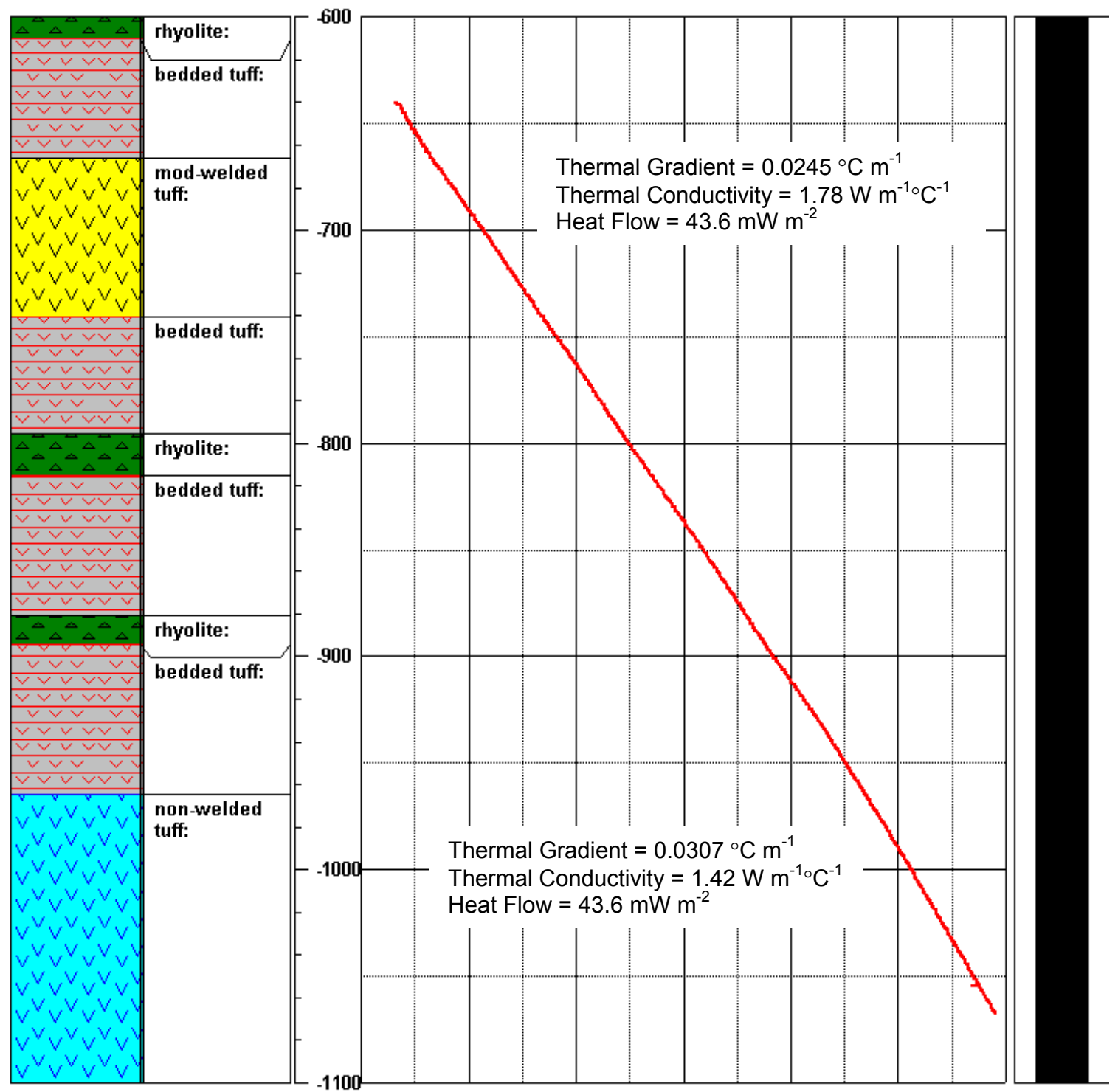

Figure 13. Temperature profile, lithology, and well construction for borehole PM-1. 

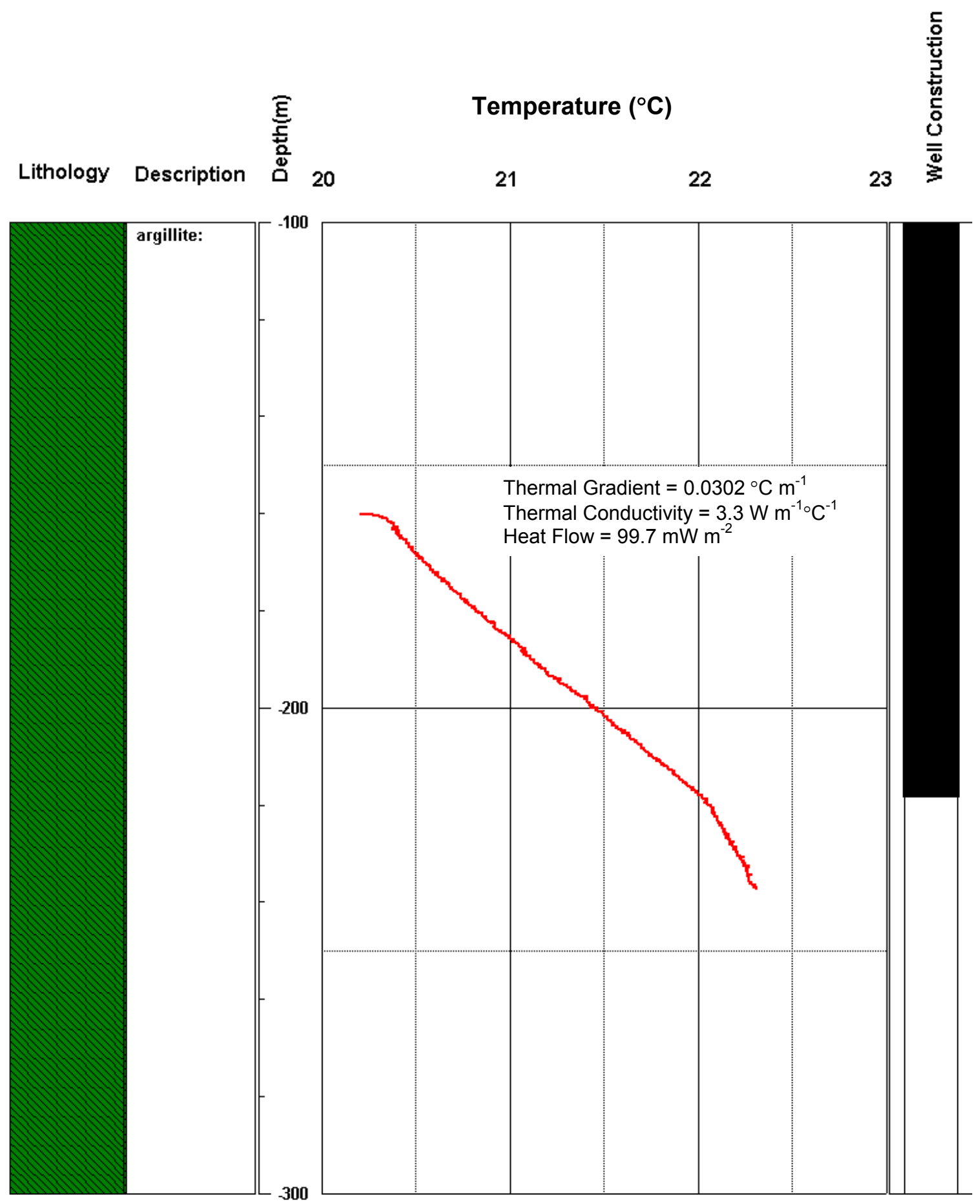

Figure 14. Temperature profile, lithology, and well construction for borehole UE-11.

The temperature profile for UE-11 was obtained by DRI on January 28, 2002. A least-squares regression of the linear portion of the temperature profile above the base of the casing in the borehole yielded a geothermal gradient of $0.0302{ }^{\circ} \mathrm{C} \mathrm{m}^{-1}$. Using a 
thermal conductivity of $3.3 \mathrm{~W} \mathrm{~m}^{-1 \circ} \mathrm{C}^{-1}$ (Johnston et al., 1981), combined with the measured thermal gradient, results in a heat flow value of $99.7 \mathrm{~mW} \mathrm{~m}^{-2}$.

The decrease in thermal gradient below the base of the casing in UE-11 may indicate the possible presence of downward flow within the borehole below the casing. However, it is also possible a change in lithology, not described in the drilling history, may occur at the base of the casing. A change in lithology to an interval of higher thermal conductivity would also result in the decrease in the measured thermal gradient.

UE-16f

UE-16f (Figure 15) was completed on September 27, 1977, to a depth of $450.8 \mathrm{~m}$ below ground surface. Casing, $24.45 \mathrm{~cm}$ in diameter, was cemented in the borehole to a depth of $394.1 \mathrm{~m}$ below ground surface. Depth to static water level in the well is $112 \mathrm{~m}$ below ground surface, resulting in approximately $282 \mathrm{~m}$ of fluid above the bottom of the casing in the borehole. The saturated portion of the borehole above the bottom of the casing is located entirely within an argillite.

The temperature profile for UE-16f was obtained by LLNL on May 2, 1994. A least-squares regression of the linear portion of the temperature profile above the base of the casing in the borehole yielded a geothermal gradient of $0.0288{ }^{\circ} \mathrm{C} \mathrm{m}^{-1}$. Using a thermal conductivity of $3.3 \mathrm{~W} \mathrm{~m}^{-1}{ }^{\circ} \mathrm{C}^{-1}$ (Johnston et al., 1981), combined with the measured thermal gradient, results in a heat flow value of $95.0 \mathrm{~mW} \mathrm{~m}^{-2}$.

The decrease in apparent thermal gradient below the base of the casing in UE-16f may indicate the possible presence of downward flow within the borehole below the casing.

UE-17a

UE-17a (Figure 16) was completed on July 2, 1976, and recompleted on September 23, 1976, to a depth of $370 \mathrm{~m}$ below ground surface. Casing, $11.43 \mathrm{~cm}$ in diameter, was cemented in the borehole to a depth of $368.8 \mathrm{~m}$ below ground surface. Depth to static water level in the well is $193.5 \mathrm{~m}$ below ground surface resulting in approximately $175 \mathrm{~m}$ of fluid above the bottom of the casing in the borehole. The saturated portion of the borehole above the bottom of the casing is located entirely within a quartzite.

The temperature profile for UE-17a was conducted by LLNL on May 2, 1994. Although the borehole is cased, the temperature profile from UE-17a appears to indicate downward flow below approximately $250 \mathrm{~m}$ below ground surface. This flow most likely occurs in the annular space between the casing and the borehole and is the result of inadequate seal between the casing and the borehole. A least-squares regression of the linear portion of the temperature profile above the portion of the temperature profile that appears to be disturbed by flow in the annulus yielded a geothermal gradient of $0.019{ }^{\circ} \mathrm{C} \mathrm{m}^{-1}$. Johnston et al. (1981) published thermal conductivity values for quartzite ranging from 4.5 to $7.1 \mathrm{~W} \mathrm{~m}^{-1}{ }^{\circ} \mathrm{C}^{-1}$. Combined with the measured gradient of $0.019{ }^{\circ} \mathrm{C} \mathrm{m}^{-1}$, these thermal conductivity values would result in a range of heat flow from 85.5 to $134.9 \mathrm{~mW}$ $\mathrm{m}^{-2}$. Using an average thermal conductivity of $5.8 \mathrm{~W} \mathrm{~m}^{-1}{ }^{\circ} \mathrm{C}^{-1}$, combined with the measured thermal gradient, results in a heat flow value of $110.2 \mathrm{~mW} \mathrm{~m}^{-2}$. 

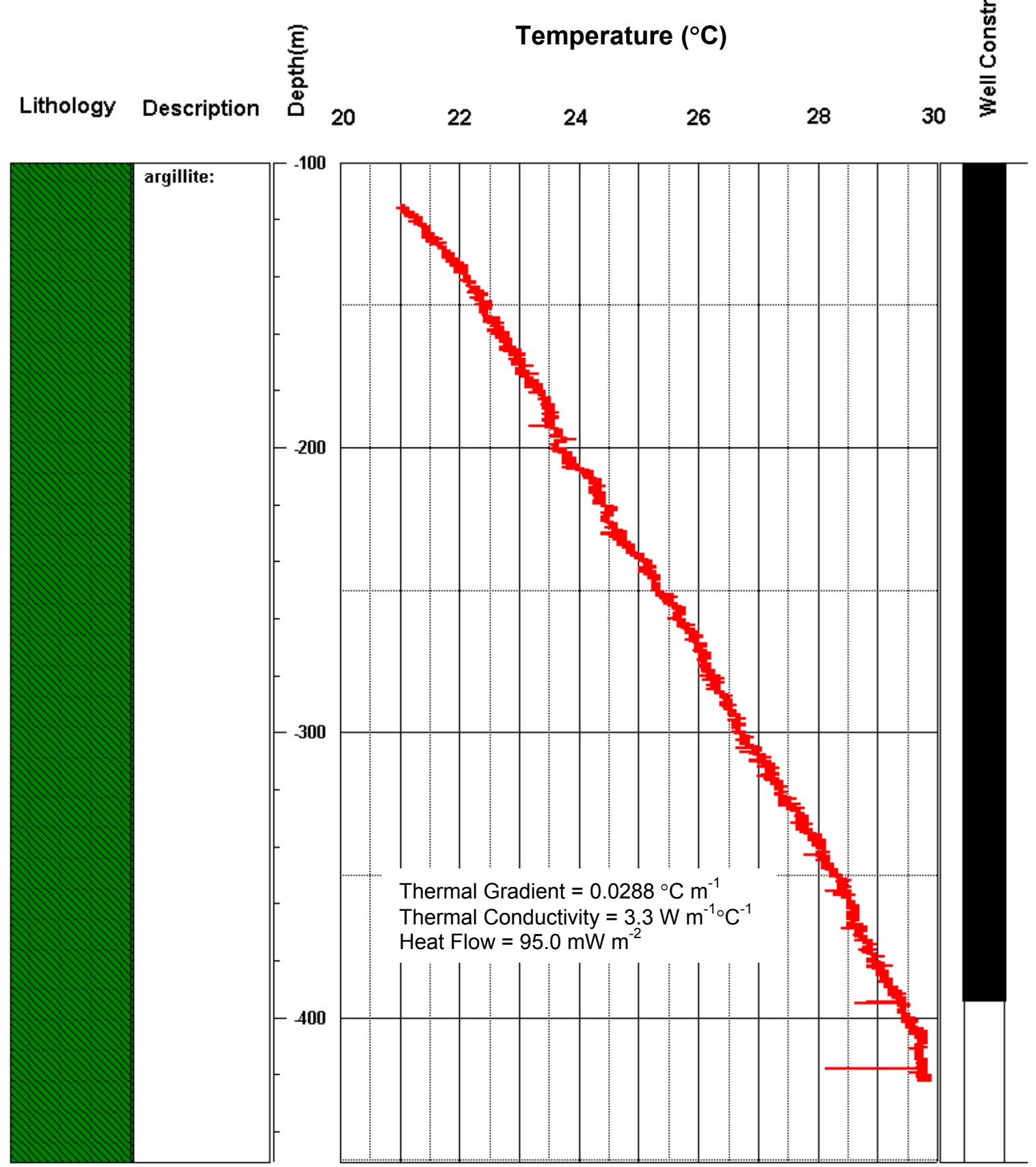

Figure 15. Temperature profile, lithology, and well construction for borehole UE-16f. 

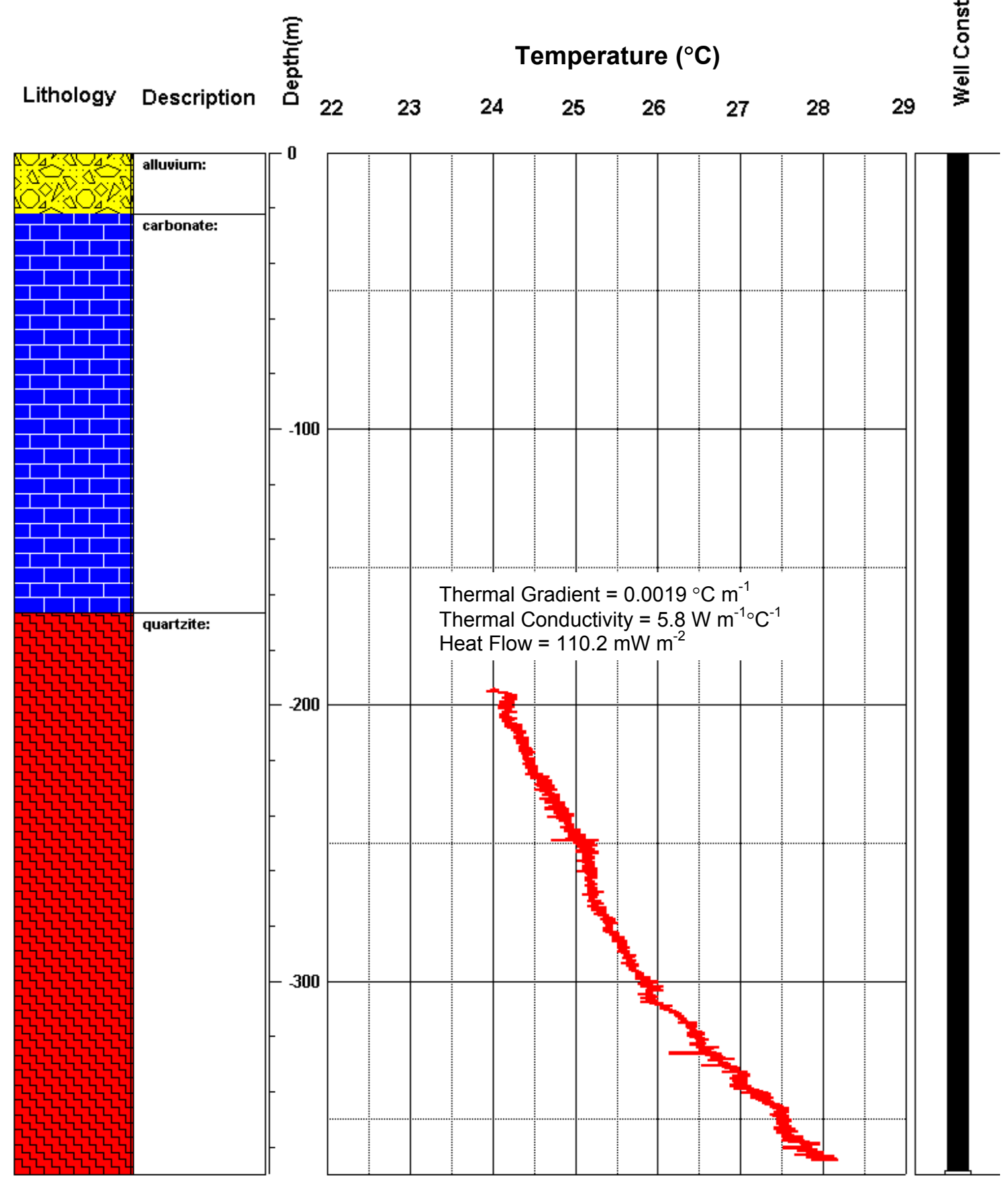

Figure 16. Temperature profile, lithology, and well construction for borehole UE-17a. 
UE-2ce

UE-2ce (Figure 17) was completed on January 25, 1977, to a depth of $502.92 \mathrm{~m}$ below ground surface. Casing, $21.0 \mathrm{~cm}$ in diameter, was cemented in the borehole to a depth of $495 \mathrm{~m}$ below ground surface. Depth to static water level in the well is $441.5 \mathrm{~m}$ below ground surface, resulting in approximately $53 \mathrm{~m}$ of fluid above the bottom of the casing in the borehole. The saturated portion of the borehole above the bottom of the casing is located entirely within Paleozoic carbonate rock.

The temperature profile for UE-2ce was conducted by DRI on January 28, 2002. The temperature log was stopped at $459 \mathrm{~m}$ below ground surface to prevent exiting the access tubing for the well. A least-squares regression of the linear portion of the temperature profile above the base of the casing in the borehole yielded a geothermal gradient of $0.0015^{\circ} \mathrm{C} \mathrm{m}^{-1}$. Using a thermal conductivity of $5.0 \mathrm{~W} \mathrm{~m}^{-1} \mathrm{C}^{-1}$ (Sass et al., 1987), combined with the measured thermal gradient, results in a heat flow value of $7.5 \mathrm{~mW} \mathrm{~m}^{-2}$.

The extremely low heat flow value estimated from the temperature profile from UE-2ce suggests significant horizontal flow within the carbonate aquifer has effectively increased the thermal conductivity of the aquifer.

Amargosa Test Hole \#1 and Amargosa Test Hole \#2

Amargosa Test Hole \#1 (ATH1) and Amargosa Test Hole \#2 (ATH2) are located southwest of the NTS (Figure 4). The two boreholes are located approximately $123 \mathrm{~m}$ from one another.

ATH1 (Figure 18) was completed on August 12, 1966, to a depth of $311.5 \mathrm{~m}$ below ground surface. Casing, $24.4 \mathrm{~cm}$ in diameter, was cemented in the borehole to a depth of $228.6 \mathrm{~m}$ below ground surface. The bottom $16.8 \mathrm{~m}$ of this casing were perforated. Depth to static water level in the well is $14 \mathrm{~m}$ below ground surface, resulting in approximately $197.8 \mathrm{~m}$ of fluid above the top of the perforated casing in the borehole.

The temperature profile for ATH1 was conducted by DRI on February 15, 2002. As seen in Figure 18, a slight change in temperature gradient occurs at the basalt unit located within the alluvium. A pronounced change in gradient can be seen at the contact between the alluvium and the dolomite/carbonate lithologies. The average thermal gradient above the contact between the alluvium and dolomite/carbonate lithologies penetrated by the borehole yields a geothermal gradient of $0.0623{ }^{\circ} \mathrm{C} \mathrm{m}^{-1}$. Using an thickness-weighted harmonic mean thermal conductivity of $1.21 \mathrm{~W} \mathrm{~m}^{-1} \mathrm{C}^{-1}$ for the alluvium and the basalt units (Sass et al., 1987), combined with the measured thermal gradient, results in a heat flow value of $75.4 \mathrm{~mW} \mathrm{~m}^{-2}$. Within the carbonate units the thermal gradient is $0.0013{ }^{\circ} \mathrm{C} \mathrm{m}^{-1}$. Using a thermal conductivity of $5.0 \mathrm{~W} \mathrm{~m}^{-1}{ }^{\circ} \mathrm{C}^{-1}$ for the carbonate units results in a calculated heat flow of $6.5 \mathrm{~mW} \mathrm{~m}^{-2}$. 

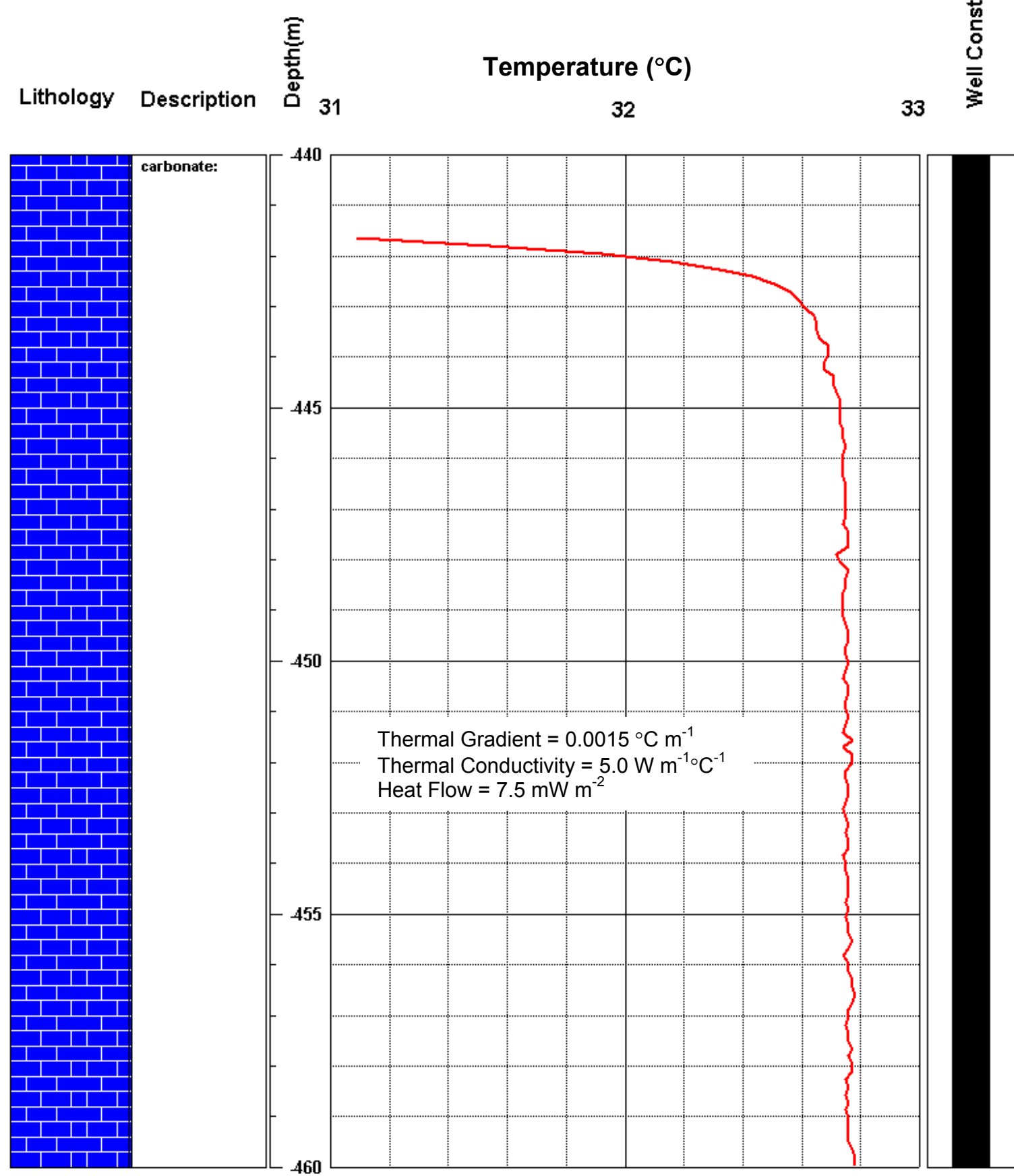

Figure 17. Temperature profile, lithology, and well construction for borehole UE-2ce. 

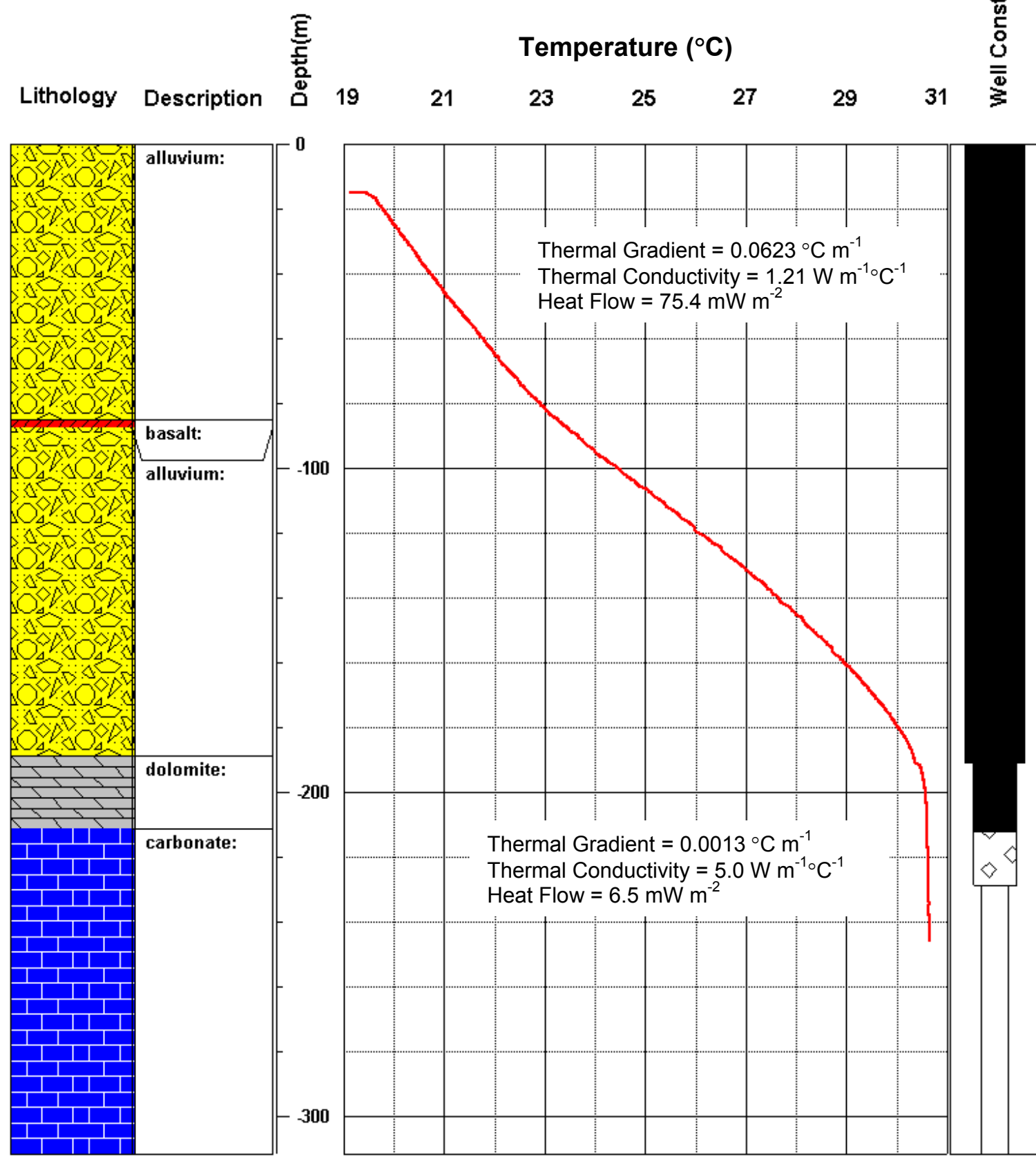

Figure 18. Temperature profile, lithology, and well construction for borehole Amargosa Test Hole \#1. 
ATH2 (Figure 19) was completed on August 11, 1966, to a depth of $252.4 \mathrm{~m}$ below ground surface. Casing, $19.4 \mathrm{~cm}$ in diameter, was cemented in the borehole to a depth of $236.2 \mathrm{~m}$ below ground surface. The bottom $11.3 \mathrm{~m}$ of this casing was perforated. Depth to static water level in the well is $12 \mathrm{~m}$ below ground surface, resulting in approximately $212.9 \mathrm{~m}$ of fluid above the top of the perforated casing in the borehole.
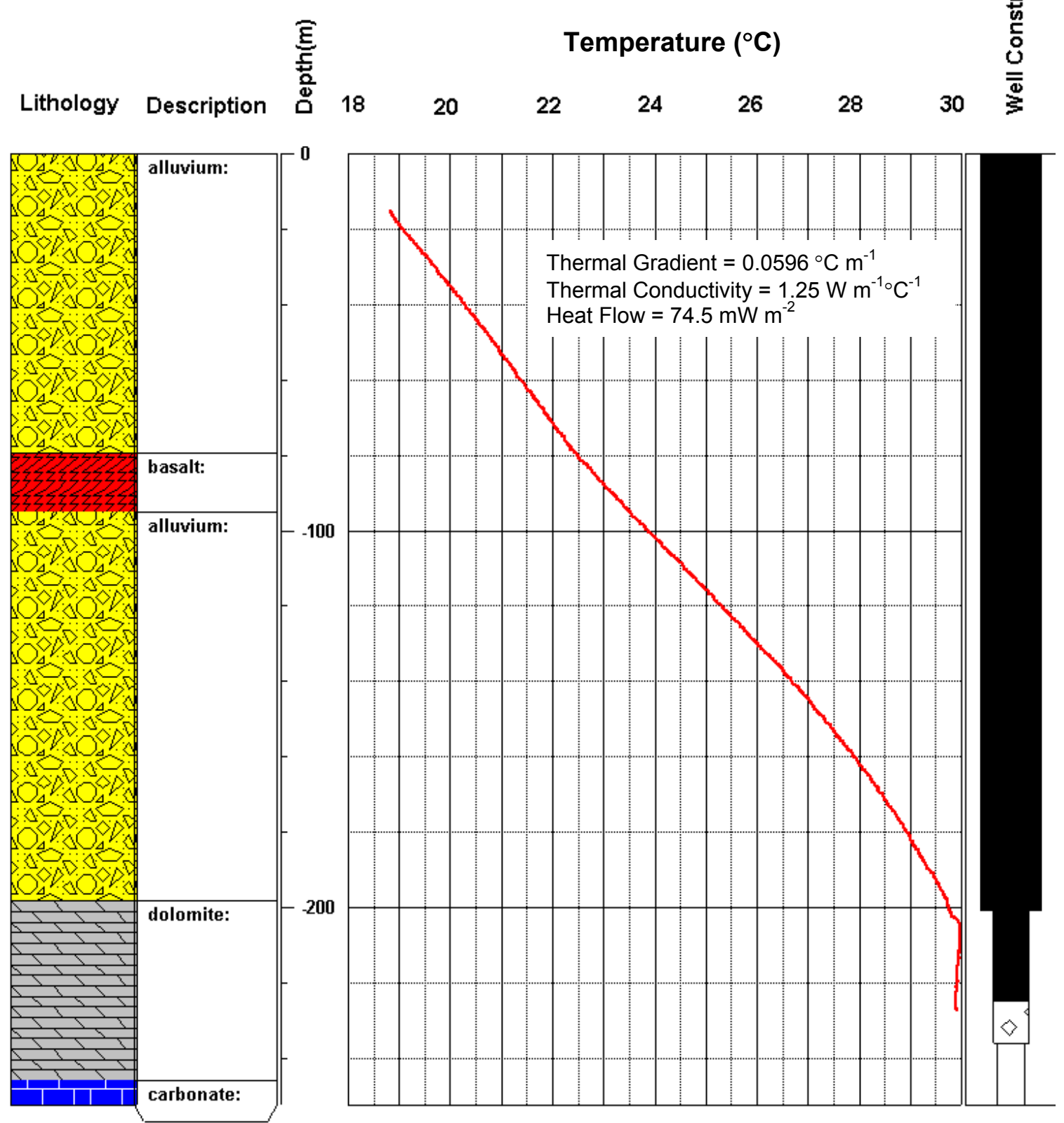

Figure 19. Temperature profile, lithology, and well construction for borehole Amargosa Test Hole \#2. 
The temperature profile for ATH2 was obtained by DRI on February 15, 2002. As seen in Figure 19, a slight change in temperature gradient occurs at the top of the basalt unit located within the alluvium. A pronounced change in gradient can be seen at the contact between the alluvium and the dolomite lithologies. The average thermal gradient above the contact between the alluvium and dolomite lithologies penetrated by the borehole yields a geothermal gradient of $0.0596{ }^{\circ} \mathrm{C} \mathrm{m}^{-1}$. Using a thickness-weighted harmonic mean thermal conductivity of $1.25 \mathrm{~W} \mathrm{~m}^{-1}{ }^{\circ} \mathrm{C}^{-1}$ for the alluvium and the basalt unit (Sass et al., 1987), combined with the measured thermal gradient, results in a heat flow value of $74.5 \mathrm{~mW} \mathrm{~m}^{-2}$. Within the carbonate units, the thermal gradient is vertical or reversed. A reversed gradient (decrease in temperature with depth) would appear to indicated the presence of downward heat flow, however, a more likely explanation would be an actual cooling (the advective removal of heat) of the carbonate units due to considerable horizontal flow.

\section{DISCUSSION}

Figure 20 shows the location and heat flow values for the 13 boreholes investigated in this study. The only heat flow value calculated from a borehole common between this investigation and the investigation of Sass and Lachenbruch (1982) is borehole PM-1. Sass and Lachenbruch (1982) calculated a heat flow value of $42 \mathrm{~mW} \mathrm{~m}^{-2}$ (Table 1); the current investigation calculated a heat flow value for PM-1 of $43.6 \mathrm{~mW} \mathrm{~m} \mathrm{~m}^{-}$ 2 . These heat flow values for borehole PM-1 only differ by $1.6 \mathrm{~mW} \mathrm{~m}^{-2}(<4 \%)$ and are in good agreement.

In this study, heat flow values were obtained in the Paleozoic carbonate aquifer in four boreholes, ATH1, ATH2, UE-1q, and UE-2ce. In UE-1q, heat flow values in the carbonate aquifer and overlying volcanic tuff aquitard were remarkably similar, approximately $30 \mathrm{~mW} \mathrm{~m}^{-2}$ ), indicating the absence of advection of heat by groundwater flow within the aquifer. In boreholes ATH1 and ATH2, the average heat flow in the overlying alluvium and tuff units was determined to be approximately $75 \mathrm{~mW} \mathrm{~m}$; however, within the carbonate aquifer, the calculated heat flow values, given the vertical to slightly negative thermal gradients would have been near zero $\mathrm{mW} \mathrm{m}^{-2}$. In UE-2ce, the calculated heat flow in the carbonate aquifer is $7.5 \mathrm{~mW} \mathrm{~m}^{-2}$. The most likely explanation for the extremely low apparent heat flow values in the carbonate aquifer at ATH1 and ATH2 is the presence of significant horizontal flow within the aquifer, with mixing and dispersion of heat produced by the groundwater movement acting to effectively increase the thermal conductivity of the carbonate unit. The heat flow value calculated for the carbonate aquifer at UE-2ce was also extremely low $\left(7.5 \mathrm{~mW} \mathrm{~m}^{-2}\right)$, indicating the presence of groundwater flow within the carbonate aquifer penetrated by the borehole.

Anomalously high heat flow values were estimated in boreholes UE-17a, UE-16f, and UE-11 (Figures 4 and 21). These boreholes are located in the vicinity of Syncline Ridge on the western edge of Yucca Flat and penetrate argillites and quartzites. Unlike vast portions of the NTS, the Syncline Ridge area does not contain volcanic rocks and there is very little alluvium. A likely explanation for the high heat flow values estimated in the area around Syncline Ridge is that heat flow is refracted away from areas covered with lower thermal conductivity alluvium and volcanic units and channeled towards the area near Syncline Ridge, where higher thermal conductivity quartzites, argillites, and carbonate units overlie basement rocks. 


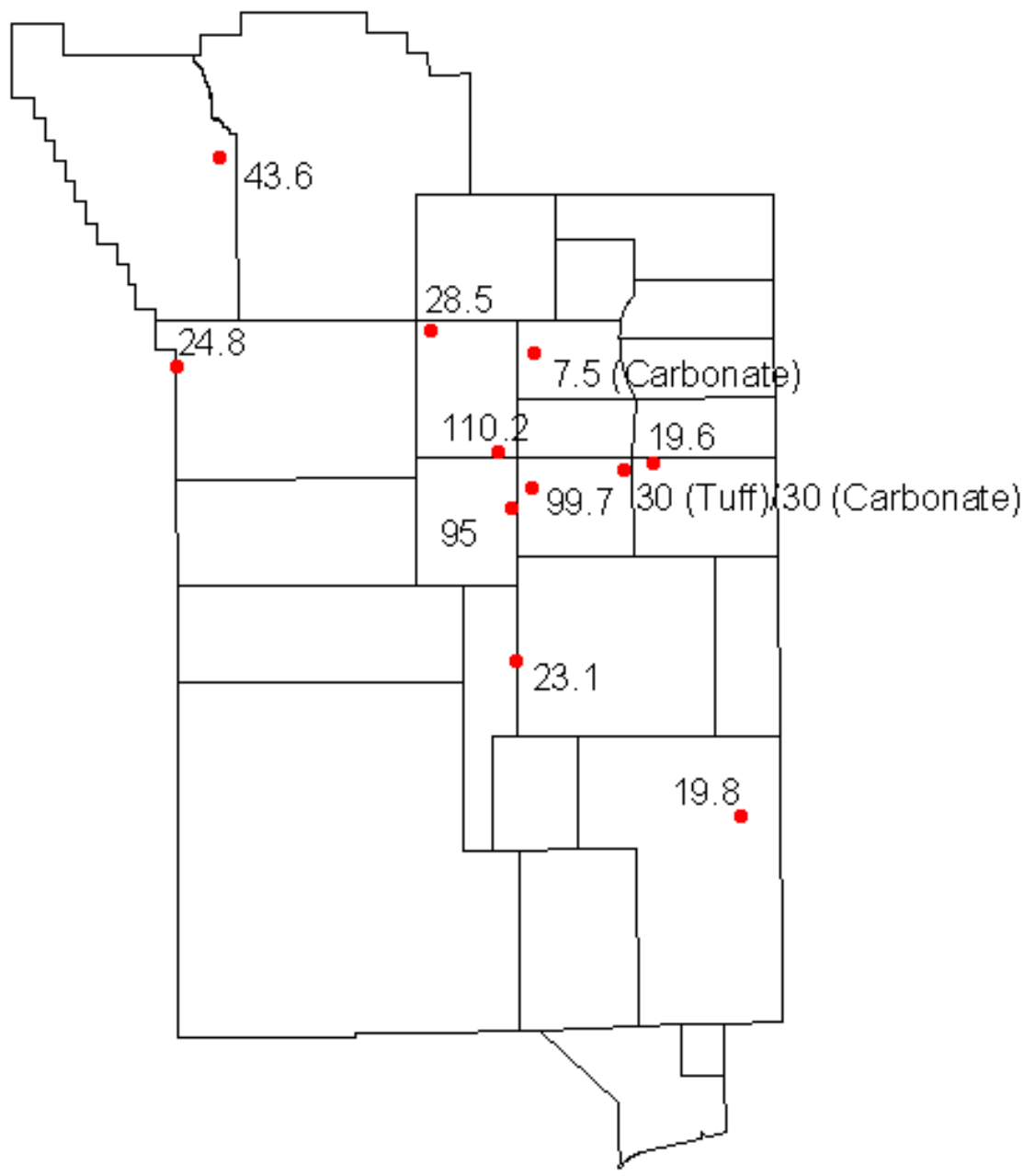

75.4

74.5

Figure 20. Heat flow values for 13 wells investigated in this study.

PM-1 (Figure 13), located on Pahute Mesa, displayed remarkable linear thermal gradients with vertically consistent heat flow values of $43.6 \mathrm{~mW} \mathrm{~m}^{-2}$. This would seem to indicate the absence of either vertical or horizontal groundwater flow within the hydrologic units penetrated by the borehole.

The heat flow value calculated for UE-18r, located on Buckboard Mesa, was $24.8 \mathrm{~mW} \mathrm{~m} \mathrm{~m}^{-2}$, approximately one-half of the heat flow estimated at PM-1. The temperature profile present in UE-18r below the casing indicated significant downward fluid movement within the borehole. If downward flow were present within the volcanic units in this portion of NTS, this would explain the somewhat lower heat flow values estimated at UE-18r as compared to PM-1. 
ATH1 and ATH2 are located in the Amargosa Valley southwest of the NTS, within $123 \mathrm{~m}$ from one another. Composite heat flow values for the alluvium and basalt units overlying the dolomite and limestone aquifers in both boreholes were similar, as one would expect: 75.4 and $74.5 \mathrm{~mW} \mathrm{~m}^{-2}$, respectively. Temperature profiles measured in the cased portions of the boreholes penetrating the aquifer displayed extremely low $\left(6.5 \mathrm{~mW} \mathrm{~m}^{-2}\right)$ to negative thermal gradients. As with the thermal gradient estimated in the carbonate aquifer penetrated by UE-2ce, low thermal gradients and corresponding low calculated apparent heat flows within the carbonate aquifers in these boreholes indicate significant horizontal groundwater flow at these locations. The negative thermal gradient seen in borehole ATH2 may be the result of significant advective heat transport due to groundwater flow actually reducing the temperature of the carbonate units penetrated by the wellbore. This concept appears to be supported by the difference in average temperatures measured within the carbonate units within the two boreholes (Figure 19). The average temperature within the carbonate units in borehole ATH1 is about $1.5{ }^{\circ} \mathrm{C}$ warmer than within the carbonate units in borehole ATH2.

Additionally, both ATH1 And ATH2 temperature profiles display significant convex upward curvatures of the temperature profiles within the alluvium interval between the carbonate and basalt lithologies penetrated by the boreholes. These curvatures may be indicative of upward flow with the alluvium between the carbonate aquifer and the basalt units in this area. Within the alluvium intervals of both boreholes, the upper intervals of alluvium display smaller gradients than the lower intervals. Assuming the thermal conductivities of the upper and lower alluvium intervals are the same, this would suggest a reduction in heat flow in the upper alluvium intervals compared to the lower alluvium intervals. A possible explanation for this reduction in heat flow would be the removal of heat energy through advection by horizontal fracture flow within the basalt units.

The lowest heat flows, which did not appear to be affected by groundwater flow, were estimated in boreholes TW-7 and UE-5n, with values of 19.6 and $19.8 \mathrm{~mW} \mathrm{~m} \mathrm{~m}^{-2}$, respectively. The low heat flow value calculated for borehole UE-5n is easily explained by the borehole's location in central Frenchman Flat. The depth to the carbonate aquifer beneath Frenchman Flat in the vicinity of UE-5n is estimated to be greater than approximately 2,000 $\mathrm{m}$ below ground surface (IT Corp., 2001). The thick section of low thermal conductivity tuffs and alluvium overlying the carbonate aquifer would tend to deflect heat away from the center of Frenchman Flat and towards the edges of the basin. TW-B, although located only 2,240 m east-northeast of UE-1q, displayed a heat flow value of $19.6 \mathrm{~mW} \mathrm{~m}^{-2}$, while the heat flow value at UE-1q was calculated to be approximately $30 \mathrm{~mW} \mathrm{~m}^{-2}$. Phelps and McKee (1999) examined gravity data to determine the surface elevation of the carbonate aquifer in Yucca Flat. Their results indicated that approximately 800-m-thick sections of tuffs and alluvium overly the carbonate aquifer in the vicinity of TW-7 relative to UE-1q.

\section{CONCLUSIONS}

In this investigation, 145 temperature logs from 63 boreholes on, or near, the NTS were examined. Of these, 13 boreholes were found to have temperature profiles suitable for the determination of heat flow values from one or more intervals within the boreholes. Heat flow values for intervals contained within the 13 boreholes ranged from a low of 


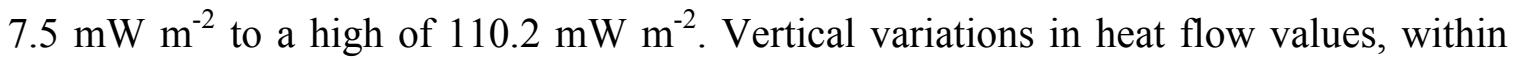
individual boreholes, were readily explained by the advection of heat by groundwater flow. Horizontal consistencies and variations in heat flow values between various boreholes were dependent upon the geologic setting of the borehole, and the effect of vertical fluid movement.

Of the 145 temperature logs examined in this study, 88 were obtained less than one year after completion of the borehole from which they were acquired (two logs did not contain information indicating the date on which the logs were obtained). The majority of the $55 \operatorname{logs}$ obtained more than one year after construction of the borehole were acquired by LLNL or DRI in conjunction with radionuclide migration or hydrologic investigations. Because most temperature logs archived at the NTS were obtained in conjunction with other geophysical logs immediately following construction of a borehole, examination of analog (paper) temperature profiles archived at the NTS would probably not be productive. Although, without a doubt, a wealth of data exists in paper logs archived at the NTS, a large effort would be required to review all those logs and then digitize the most useful ones. This investigation most likely reviewed all the readily available temperature logs from the NTS that were obtained more than one year after completion of the borehole. However, as the utility of temperature logs in model calibration becomes more evident, it may at some point become desirable to expend the considerable effort necessary to mine the wealth of data present in paper logs archived at the NTS.

Additionally, of the 13 borehole temperature profiles used in this study, only one borehole (UE-18r) had been logged more than once, with subsequent temperature profiles sufficiently separated in time, to ensure thermal stability of the borehole fluids. In this study, the somewhat arbitrary limit of one year was used to determine whether a borehole had returned to thermal equilibrium following construction. The actual time required for a borehole to return to thermal equilibrium following construction depends on many factors: borehole diameter, length of time required to drill, amount of drilling fluid circulated during drilling, etc. To ensure a borehole is in thermal equilibrium with the surrounding formations, two identical temperature profiles, obtained sufficiently separate in time, must be obtained.

Because groundwater temperature is sensitive to conductive and advective processes, groundwater temperature may be utilized as a tracer to further constrain the uncertainty of predictions of advective radionuclide transport models constructed for the NTS. Since heat transport, hydrologic and geochemical models for a given area must all be consistent, uncertainty can be reduced by devaluing the weight of those models that do not match estimated heat flow. Ambient heat flow information, such as presented in this report, could serve as input for heat flux boundary conditions for flow modeling at the NTS. Additional borehole temperature profiles that have been clearly impacted by groundwater flow need to be identified and used to constrain the flow modeling.

Because heat flow data and hydrologic data are both obtained from boreholes, if every borehole used to obtain hydrologic data was temperature logged, it would be possible to have at least as many data points for a heat transport model as for the hydrologic model. Of all the boreholes constructed for the Underground Test Area program, none had been temperature logged more than one year after construction. Prior 
to yearly sampling, a temperature log should be obtained from these wells to determine heat flow values for the borehole. Additionally, other boreholes previously logged should be re-logged to ensure thermal stability of the borehole.

Temperature profiles are extremely easy and inexpensive to obtain. Considerable hydrologic information can be determined from the examination of a single temperature profile; however, if sufficient spatially distributed heat flow values are obtained, a heat transport model of the NTS could be used to reduce the uncertainty of non-isothermal hydrologic models. 


\section{REFERENCES}

Auld, M.J., 1948. Temperature gradients for convection in well models. Journal of Applied Physics, 19, 218.

Beck, A.E., 1992. Inferring past climate change from subsurface temperature profiles: Some problems and methods. Palaeogeogr. Palaeoclimatol. Palaeoecol. (Global Planet. Change Sect.), 98: 73-80.

Beltrami, H. and Taylor, A.E., 1995. Records of climatic change in the Canadian Arctic: Towards calibrating oxygen isotope data with geothermal data. Global and Planetary Change, 11: 127-138.

Birch, F., 1947. Temperature and heat flow in a well near Colorado Springs, Am. J. Sci. 245, pp. 733-753.

Bullard, E.C., 1939. Heat flow in South Africa. Proc. R. Soc. London, A173(995), pp. 474-502.

Chapman, D.S., M.D. Clement and C.W. Mase, 1981. Thermal regime of the Escalante Desert, Utah, with an analysis of the Newcastle Geothermal System. J. Geophys. Res., 86(B12), pp. 11,735-11,746.

Chisholm, T. J. and D.S. Chapman, 1992. Climate change inferred from borehole temperatures: An example from western Utah. J. Geophys. Res.,97: 14155-14176.

Deming, D. and R.A. Borel, 1995. Evidence for climatic warming in north central Oklahoma from analysis of borehole temperatures. J. Geophys. Res., vol. 100, p. 22,017-22,032.

Diment, W.H., 1967. Thermal regime of a large diameter borehole: Instability of the water column and comparison of air- and water-filled conditions. Geophysics, 32(4), 720-726.

Fridrich, C.J., W.W. Dudley and J.S. Stuckless, 1994. Hydrogeologic analysis of the saturated-zone ground-water system, under Yucca Mountain, Nevada, Journal of Hydrology, 154, pp. 133-168.

Gretener, P.E., 1967. On the thermal instability of large diameter wells - an observational report. Geophysics, 32(4), 727-738.

Hales, A.L., 1937. Convection currents in geysers. Monthly Notices of the Royal Astronomical Society, Geophysics Supplement, 4, 122-131.

Huang, S., H.N. Pollack and P.Y. Shen, 2000. Temperature trends over the past five centuries reconstructed from borehole temperatures. Nature, 403: 756-758.

Hunt, J.M., M.D. Lewan and R.J. Hennet, 1991. Modeling oil generation with timetemperature index graphs based on the Arrhenius equation. AAPG Bulletin, 75(4), $795-807$.

IT Corporation, 2001. Addendum to the Frenchman Flat Hydrogeologic Investigation Wells Drilling and Completion Criteria, Revision No.: 1, ITLV/13052-094-REV. 1ADD. 
Johnston, G.H., B. Ladanyi, N.R. Morgenstern and E. Penner, 1981. Engineering Characteristics of Frozen and Thawing Soils. Permafrost Engineering Design and Construction. Edited by Johnston, G.H. John Wiley \& Sons.

Lachenbruch, A.H., M.L. Sorey, R.E. Lewis and J.H. Sass, 1976. The near-surface hydrothermal regime of Long Valley Caldera. J. Geophys. Res., 81, 763-768.

Lopatin, N.V., 1976. The influence of temperature and geologic time on the catagenetic processes of coalification and petroleum and gas formation. In Isseledovaniya Organicheskogo Veshchestva Sovremennykh i Iskopayemykh Osakdov (Study of Organic Matter in Recent and Old Sediments), pp.361-6. Moscow: Nauka Press.

Lowrie, A., R. Hamiter, M.A. Fogarty, T. Orsi and I. Lerche, 1996. Thermal and timetemperature index (TTI) patterns during geologic evolution of north and central Gulf of Mexico. In AAPG Bulletin, 80(9), Abstracts of Meeting: AAPG Gulf Coast Association of Geological Societies, San Antonio, Texas, United States, October 2-4, 1996, p.1508. Tulsa, Oklahoma: American Association of Petroleum Geologists.

Phelps G.A. and E.H. McKee, 1999. High-angle faults in the basement of Yucca Flat, Nevada Test Site, Nevada, based on analysis of a constrained gravity inversion surface: U.S. Geological Survey Open-File Report 99-383, 11 p.

Pollack, H.N., 1993. Climate change inferred from borehole temperatures. Palaeogeogr. Palaeoclimatol. Palaeoecol. (Global Planet. Change Sect.), 99: 173-179.

Pollack, H.N., S.J. Hurter and J.R. Johnson, 1993. Heat flow from the Earth's interior: Analysis of the global data set. Reviews of Geophysics, 31(3), 267-280.

Pottorff, E.J., S.J. Erikson and M.E. Campana, 1987. Hydrologic Utility of Borehole Temperatures in Areas 19 and 20, Pahute Mesa, Nevada Test Site. Desert Research Institute publication \#45060.

Reiter, M., A.J. Mansure and C. Shearer, 1979. Geothermal characteristics of the Rio Grande Rift within the southern Rocky Mountain complex, In Rio Grande Rift: Tectonics and Magnetism, R.E. Reicker (ed.), pp. 253-267, AGU, Washington, D.C.

Sass, J.H., A.H. Lachenbruch and C.W. Mase, 1980. Analysis of thermal data from drill holes UE25a-3 and UE25a-1, Calico Hills and Yucca Mountain, Nevada Test Site. U.S. Geological Survey Open-File Report 80-826, 25 p.

Sass, J.H. and A.H. Lachenbruch, 1982. Preliminary interpretation of thermal data from the Nevada Test Site. U.S. Geological Survey Open-File Report 82-973, 30 p.

Sass, J.H., A.H. Lachenbruch, W.W. Dudley, S.S. Priest and R.J. Munroe, 1987. Temperature, thermal conductivity, and heat flow near Yucca Mountain, Nevada: Some tectonic and hydrologic implications. U.S. Geological Survey Open-File Report, 87-649, 118 p.

Smith, L. and D.S. Chapman, 1983. On the thermal effects of groundwater flow 1. Regional scale systems, J. Geophys. Res., 88(B1), pp. 593-608. 
Urban, T.T., W.H. Diment and M. Nathenson, 1978. East Mesa geothermal anomaly, Imperial County, California: Significance of temperature in a deep drill hole near thermal equilibrium. In Geothermal Energy: A Novelty Becomes Resource (Transactions of Meeting, Hilo, Hawaii, July 25-27), vol. 2(2), ed. J. Combs, pp. 667670. Davis, California: Geothermal Resource Council.

Van Orstrand, C.E, 1934. Temperature gradients, In Problems of Petroleum Geology, pp. 989-1021. American Association of Petroleum Geologists, Tulsa, Okla.

Whiteford, P., 1993. Evaluation of past climate using borehole temperature measurements. Weather and Climate, 13: 3-8.

Wisian, K.W., D.D. Blackwell, S. Bellani, J.A. Henfling, R.A. Normann, P.C. Lysne, A. Forster and J. Schrotter, 1998. Field comparison of conventional and new technology temperature logging systems. Geothermics, 27(2), 131-141.

Woodbury, A.D. and L. Smith, 1985. On the thermal effects of three-dimensional groundwater flow. J. Geophys. Res., 90(B1), pp. 795-767.

Wright, J.A. and K.E. Louden, 1989. CRC Handbook of Sea Floor Heat Flow. CRC Press, Inc., Boca Raton, FL, p. 197. 


\section{DISTRIBUTION}

Jim Aldrich

Los Alamos National Laboratory

P.O. 1663, M/S D-462

Los Alamos, NM 87545

Bob Bangerter

Environmental Restoration Division

Nevada Site Office

National Nuclear Security Administration

U.S. Department of Energy

P.O. Box 98518

Las Vegas, NV 89193-8518

Rick Betteridge, Director

Technology Division

Nevada Site Office

National Nuclear Security Administration

U.S. Department of Energy

P.O. Box 98518

Las Vegas, NV 89193-8518

Melody Bell

Office of Business Affairs

Nevada Site Office

National Nuclear Security Administration

U.S. Department of Energy

P.O. Box 98518

Las Vegas, NV 89193-8518

Jeff Daniels

Lawrence Livermore National Laboratory

P.O. Box 808

M/S J514 CST-7

Livermore, CA 94551

Barbara Deshler

Shaw Environmental, Inc.

7710 W. Cheyenne

Las Vegas, NV 89129

Dave Finnegan

Los Alamos National Laboratory

P.O. Box 1663, M/S J-514, CST-7

Los Alamos, NM 87545
Ward Hawkins

Los Alamos National Laboratory

P.O. Box 1663, M/S F-665

Los Alamos, NM 87545

Bruce Hurley

Hydrology Program Manager

Environment, Safety \& Health Division

Nevada Site Office

National Nuclear Security Administration

U.S. Department of Energy

P.O. Box 98518

Las Vegas, NV 89193-8518

Kenneth Hoar, Director

Environment, Safety \& Health Division

Nevada Site Office

National Nuclear Security Administration

U.S. Department of Energy

P.O. Box 98518

Las Vegas, NV 89193-8518

Marjory Jones

Division of Hydrologic Sciences

Desert Research Institute

2215 Ragio Parkway

Reno, NV 89512-1095

Randy Laczniak

Water Resources Division

U.S. Geological Survey

6770 S. Paradise Rd.

Las Vegas, NV 89119

Dirk Schmidhofer

Stockpile Stewardship Division

Nevada Site Office

National Nuclear Security Administration

U.S. Department of Energy

P.O. Box 98518

Las Vegas, NV 89193-8518

Ken Ortego

Bechtel Nevada

P.O. Box 98521

Las Vegas, NV 89193-8521 
Gayle Pawloski

Lawrence Livermore National Laboratory

P.O. Box 808 L-221

Livermore, CA 94551

Ken Rehfeldt

HSI-GeoTrans

7710 W. Cheyenne

Las Vegas, NV 89129

Tim Rose

Lawrence Livermore National Laboratory

P.O. Box 808, M/S L-231

Livermore, CA 94551

Chuck Russell

Division of Hydrologic Sciences

Desert Research Institute

755 E. Flamingo Road

Las Vegas, NV 89119-7363

David Shafer

Division of Hydrologic Sciences

Desert Research Institute

755 E. Flamingo Road

Las Vegas, NV 89119-7363

Bonnie Thompson

Water Resources Division

U.S. Geological Survey

6770 S. Paradise Rd.

Las Vegas, NV 89119

Rick Waddell

HSI-GeoTrans

9101 Harlan Street, Ste. 210

Westminster, CO 80030

Janet Wille

Shaw Environmental, Inc.

7710 W. Cheyenne

Las Vegas, NV 89129

Nevada State Library and Archives

State Publications

100 North Stewart Street

Carson City, NV 89701-4285
Archives

Getchell Library

University of Nevada, Reno

DeLaMare Library/262

University of Nevada, Reno

Document Section, Library

University of Nevada, Las Vegas

4505 Maryland Parkway

Las Vegas, NV 89154

Shaw Environmental, Inc.

P.O. Box 93838

Bldg. B-1, M/S 439

Las Vegas, NV 89193-3838

ATTN: Toni Miller, M/S 439

Library

Southern Nevada Science Center

Desert Research Institute

755 E. Flaming Road

Las Vegas, NV 89119-7363

Public Reading Facility

Nevada Site Office

National Nuclear Security Administration

U.S. Department of Energy

P.O. Box 98521

Las Vegas, NV 89193-8521

Technical Library

Nevada Site Office

National Nuclear Security Administration

U.S. Department of Energy

P.O. Box 98518

Las Vegas, NV 89193-8518

Office of Scientific and Technical Information

U.S. Department of Energy

P.O. Box 62

Oak Ridge, TN 37831-9939

(electronic copy) 